\title{
Unbundling Constitutionality
}

\author{
Richard Primus $\dagger$
}

Constitutional theory features a persistent controversy over the source or sources of constitutional status, that is, over the criteria that qualify some rules as constitutional rules. This Article contends that no single criterion characterizes all of the rules that American law treats as constitutional, such that it is a mistake to think of constitutionality as a status with necessary conditions. It is better to think of constitutionality on a bundle-of-sticks model: different attributes associated with constitutionality might or might not be present in any constitutional rule. Analysts should often direct their attention more to the separate substantive properties that are associated with constitutionality than to the question of constitutional status itself.

INTRODUCTION 1080

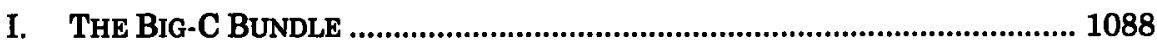

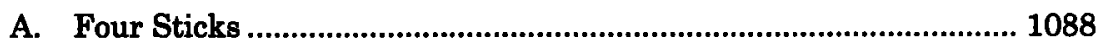

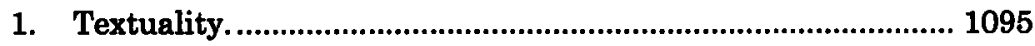

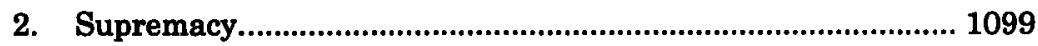

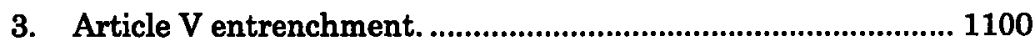

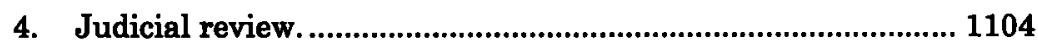

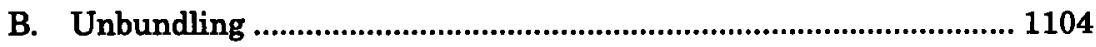

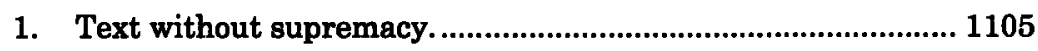

2. Text and formal entrenchment. ................................................ 1114

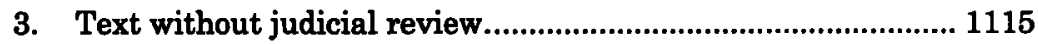

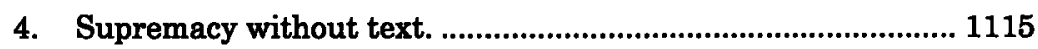

5. Supremacy without Article $V$ entrenchment............................ 1117

6. Supreme law not enforceable through judicial review............. 1117

7. Article V entrenched without text.......................................... 1119

8. Article $V$ entrenchment but not supreme law. ......................... 1122

$\dagger$ Professor of Law, The University of Michigan Law School. Research for this Article was supported in part by the Cook Foundation and in part by the John Simon Guggenheim Memorial Foundation. Thanks to Andrew Coan, Ariela Dubler, David Frisof, Monica Hakimi, Don Herzog, Doug Laycock, Jessica Morton, Robert Post, Gil Seinfeld, Larry Solum, and Mark Tushnet. I also thank the participants in workshops at Georgetown University Law Center, Princeton University, The University of Michigan Law School, and the University of Southern California School of Law. Most of all, I thank the students in my Problems in Constitutional Theory seminar, past and present, for their searching engagement with the issues discussed in this Article. 
9. Article V entrenched but not enforceable through judicial review.

10. Judicial review without text.

11. Judicial review but not supreme law.

12. Judicial review but changeable without Article $V$ amendment.

II. The SMall-c Bundle(s)

A. Six Sticks

1. Text.

1129

2. Structure.

1129

3. Ethos.

4. Judicial review.

1135

5. Supremacy.

6. Entrenchment.

B. Several Bundles

1. Classic bundles: justifying judicial review. 1140

2. Split bundles: ducking judicial review.

3. Repositioning judicial review.

\section{INTRODUCTION}

This Article is about constitutionality. Not surprisingly, that concept pervades the field we call constitutional law. We describe United States $v$ Windsor $^{1}$ as a constitutional case, free speech as a constitutional principle, ${ }^{2}$ and reverse incorporation as a constitutional doctrine. ${ }^{3}$ When the President appoints agency heads while the Senate is in pro forma session, we say that his actions raise "constitutional issues" or "constitutional concerns." 4 But what are we saying about these cases, principles, doctrines, issues, and concerns when we describe them as constitutional?5

\footnotetext{
$1 \quad 133$ S Ct 2675 (2013).

2 See, for example, Virginia v Black, 538 US 343, 359 (2003).

3 See Peter J. Rubin, Taking Its Proper Place in the Constitutional Canon: Bolling v. Sharpe, Korematsu, and the Equal Protection Component of Fifth Amendment Due Process, 92 Va L Rev 1879, 1882-83 (2006) (describing the reverse incorporation doctrine).

4 See Noel Canning v NLRB, 705 F3d 490, 493 (DC Cir 2013); Matthew C. Stephenson, Can the President Appoint Principal Executive Officers without a Senate Confirmation Vote?, 122 Yale L J 940, 942-44 (2013).

5 "Constitutional" is here the opposite of "nonconstitutional," not the opposite of "unconstitutional." To say that a rule is "constitutional" in the sense in which that term is opposed to "unconstitutional" is merely to say that the rule is constitutionally permitted. In the sense in which the term is opposed to "nonconstitutional," a rule is
} 
Characterizing a rule as constitutional might mean that it appears in the written Constitution. It might mean that the rule prevails in conflicts with other kinds of rules, that it cannot be changed by ordinary legislation, or that it can be enforced by courts even in the face of contrary action by other officials. It might mean that the rule concerns the structure of government, that it protects a fundamental American value, or that it enjoys a sacred status in American society. In one sense or another, all of the foregoing meanings point to attributes of constitutionality. But theorists disagree about the relationships among those attributes, and they disagree in particular about what entitles a rule to constitutional status in the first place. Often, the disagreement seems to concern the fundamental question of what qualifies a rule for constitutional status in something like-let's say for now-a legally authoritative sense.

The running disagreement about the basis for constitutional status often focuses on the role of the document we call the Constitution. In one family of views, a rule is constitutional if and only if it appears in, or at least derives from, the text of that document. ${ }^{6}$ If a rule is textually grounded, it enjoys constitutional status, and it is entitled to the privileged treatment that other attributes of constitutionality specify. A constitutional rule prevails in conflicts with nonconstitutional rules, is entrenched against change through ordinary legislation, and can be enforced by courts exercising the power of judicial review. Those are the payoffs of constitutional status, and textuality is the criterion. This, in capsule form, is one important approach to constitutionality. It has gone by different names at different times, including "interpretivism" 7 and then, more accurately, "textualism." 8 An

"constitutional" if it is one of the rules in light of which other rules are permitted or not. So, to use an example, "Congress may levy taxes on incomes" is an example of a constitutional rule in the sense relevant for this paper. "Capital gains income is subject to a $15 \%$ tax" is an example of a constitutional rule in the other sense. It is a rule permitted by constitutional law, not a rule of constitutional law.

6 See, for example, Antonin Scalia, A Matter of Interpretation: Federal Courts and the Law 37-41 (Princeton 1997); Sanford Levinson, Constitutional Faith 29 (Princeton 1988) (describing adherents to the "protestant" theory of constitutional textualism); John F. Manning, The Eleventh Amendment and the Reading of Precise Constitutional Texts, 113 Yale L J 1663, 1665 (2004); Akhil Reed Amar, The Supreme Court, 1999 TermForeword: The Document and the Doctrine, 114 Harv L Rev 26, $26-28$ (2000).

7 See John Hart Ely, Democracy and Distrust: A Theory of Judicial Review 1 (Harvard 1980); Thomas C. Grey, Do We Have an Unwritten Constitution?, 27 Stan L Rev 703, 710-11 (1975).

8 John F. Manning, What Divides Textualists from Purposivists?, 106 Colum L Rev 70, 73 (2006); Thomas C. Grey, The Constitution as Scripture, 37 Stan L Rev 1, 1 (1984). 
important strain in recent scholarship calls it the "big-C" approach because of the essential role that it reserves for the written Constitution-the proper noun, with a capital "C."9

A rival idea, which we can call the "small-c" approach, draws on an older and more generic meaning of the noun "constitution." 10 According to this approach, the "constitution" (with a lowercase " $c$ ") is the web of documents, practices, institutions, norms, and traditions that structure American government." Small-c theory is internally diverse, but it has a unifying theme: many constitutional rules are not grounded in the text of the big-C Constitution. ${ }^{12}$ Most small-c theorists agree that rules appearing in that document are constitutional rules, but they maintain that constitutionality can have other sources as well. To go back to the list of attributes of constitutional rules identified above, small-c theorists often hold that rules not appearing in the text are nevertheless constitutional because they are important to the structure of government or because they reflect fundamental American values. ${ }^{13}$

It should be clear that the real dispute between big-C and small-c theorists is not about the meaning of a term. Reasonable people on both sides understand that a word can carry many meanings. Small-c constitutionalists understand that in the United States the word "Constitution" names the 1787 document as amended, and big-C constitutionalists understand that there is an older sense of "constitution" that, as applied to the United States, describes something broader than that document.

9 See William N. Eskridge Jr and John Ferejohn, A Republic of Statutes: The New American Constitution 25 (Yale 2010); Levinson, Constitutional Faith at 33 (cited in note 6); Daryl J. Levinson, Parchment and Politics: The Positive Puzzle of Constitutional Commitment, 124 Harv L Rev 657, 700 (2011).

10 See Levinson, Constitutional Faith at 33 (cited in note 6); Walter Bagehot, The English Constitution 4-6 (Chapman and Hall 1867); Aristotle, Constitution of Athens and Related Texts 83, 113-16 (Hafner 1950) (Kurt Von Fritz and Ernst Kapp, trans); Levinson, 124 Harv L Rev at 700 (cited in note 9).

11 See Akhil Reed Amar, America's Unwritten Constitution: The Precedents and Principles We Live By ix-xvi (2012); Eskridge and Ferejohn, A Republic of Statutes at 12 (cited in note 9); Levinson, Constitutional Faith at 33-37 (cited in note 6); Christopher G. Tiedeman, The Unwritten Constitution of the United States: A Philosophical Inquiry into the Fundamentals of American Constitutional Law 16 (Putnam 1890); Ernest A. Young, The Constitution outside the Constitution, 117 Yale L J 408, 414 (2007).

12 See, for example, David A. Strauss, The Living Constitution 34-35 (Oxford 2010); Keith E. Whittington, Constitutional Construction: Divided Powers and Constitutional Meaning 1-9 (Harvard 1999); Philip Bobbitt, Constitutional Fate: Theory of the Constitution 93-94 (Oxford 1982).

13 See note 12. 
What is in dispute is the relationship of the constitution (with a small "c") and the Constitution (with a big " $\mathrm{C}$ ") to authoritative constitutionality in American law. After all, theorists of the different schools do not contend with each other only about how to apply the label. They generally argue in order to establish that some disputed rule is or is not entitled to be treated as supreme law, or as entrenched against revision, or as enforceable through judicial review. We argue about the basis for constitutionality in part in order to establish which rules are entitled to those privileged payoffs.

The structure of that argument points to something that most small-c theory shares with the big-C approach. On both sides of the divide, constitutionality is understood as a status that rules do or do not enjoy in light of some qualifying criteria. A known set of payoffs is then supposed to follow from constitutional status. Different small-c theories have different accounts of the qualifying criteria and of the payoffs, and not every payoff of constitutionality is claimed for every rule labeled "constitutional." But as a general matter, big-C and small-c theory alike proceed by grouping the various attributes of constitutionality together, identifying some as bases for constitutional status and others as its consequences.

My contention in this Article is that it is misleading to think of constitutionality as a status with bases and payoffs. Instead, we should think of it in the way that an earlier generation of theorists learned to understand property: as a bundle of sticks that can be separated from one another or that can be recombined in varying configurations. ${ }^{14}$ Some rules that are stated in the text of the Constitution are supreme over other rules, and some are not. Some rules that are enforceable through judicial review are in the text, and some are not. Some rules arising from structure are entrenched against revision, and some are not. And so on. No single attribute of constitutionality characterizes every rule that mainstream American practice calls "constitutional." Instead, constitutional rules exhibit a mix-and-match variety of characteristics, none of which is fully definitive of the status.

The point should be pushed a step further. Just as no single attribute is essential for constitutional status, no attribute

14 See, for example, Henry E. Smith, Property as the Law of Things, 125 Harv L Rev 1691, 1691 (2012) (describing the bundle-of-sticks conception). 
associated with constitutionality-trivial exceptions aside-is either necessary or sufficient for a rule's exhibiting any other characteristic of constitutional rules. A rule stated in the text might or might not operate as supreme law, might or might not be fundamental to the structure of government, and might or might not be enforceable through judicial review. A rule derived from the structure of government might or might not be enforceable through judicial review, might or might not require Article $\mathrm{V}$ amendment to be changed, and might or might not operate as supreme law. And so on. As a result, it is misleading to arrange the attributes of constitutionality into a set of bases and a set of payoffs, because-subject to minor exceptions-no characteristic of constitutionality necessarily follows from any other.

This claim is a form of small-c constitutionalism, but it pushes farther than most small-c theory has gone. The essential move of small-c theory is to decouple one of the attributes of constitutional status, namely textuality, from constitutionality itself. ${ }^{15}$ That move is a partial unbundling of constitutionality. But small-c theory generally does not take the project of unbundling as far as it would helpfully go. For one thing, some small-c theory shares the big-C impulse to define essential qualifying attributes of constitutional status-not textuality, but something else.16 For another, small-c theory commonly assumes that a particular set of payoffs (often including judicial review) follows from constitutional status, if only constitutionality is understood in the right way. ${ }^{17} \mathrm{My}$ point here, however, is that each of these attributes is also severable from the constitutional bundle, much as textuality is. Just as it is a mistake to think of constitutionality as the bundle of characteristics that big-C theory presents, it is generally a mistake to think of it as some other bundle of characteristics that automatically travel together.

The approach I offer might seem to make constitutional decisionmaking dangerously indeterminate. Just as conceiving of property as a bundle of sticks can make it more difficult to say who "owns" Blackacre, ${ }^{18}$ understanding constitutionality as a

15 See, for example, David A. Strauss, Common Law Constitutional Interpretation, $63 \mathrm{U}$ Chi L Rev 877, 883 (1996) ("It is the rare constitutional case in which the text plays any significant role."). See also Levinson, Constitutional Faith at 54-89 (cited in note 6); Tiedeman, The Unwritten Constitution at 155 (cited in note 11).

16 See, for example, K.N. Llewellyn, The Constitution as an Institution, 34 Colum L $\operatorname{Rev} 1,22$ (1934) (describing "highly probable permanence" as the "one essential criterion").

17 See Part II.B.

18 See Smith, 125 Harv L Rev at 1691-92 (cited in note 14). 
bundle of sticks can make it more problematic to say that a given rule is, or is not, constitutional. Suppose that American law does feature (1) rules fundamental to the structure of government but not enforceable by judicial review, (2) rules enforced by judicial review but not stated in the text, (3) rules stated in the text that do not operate as supreme law, and (4) rules that operate as supreme law but can be changed without formal amendment. Which of these are constitutional rules? On the common premise that the distinction between constitutional and nonconstitutional rules tells decisionmakers which rules to treat as supreme, entrenched, and eligible for judicial review, there needs to be a way to answer this question. How, after all, can a judge exercise the power of judicial review unless he knows which rules are constitutional? And how can he know which rules are constitutional without an account of what qualifies as constitutionality?

There is something sensible to this worry. Judicial review should not be exercised cavalierly or idiosyncratically. Hence the venerable tradition of trying to discipline its exercise with objective criteria, textual or otherwise.19 But sorting carefully through the idea of unbundled constitutionality should reveal that the indeterminacy it creates is less of a practical problem than might be feared. Yes, disaggregating constitutionality into separate components might make it more difficult, or just less meaningful, to distinguish between rules that are constitutional and those that are not. But it also strips the distinction of its power to decide which rules may be judicially enforced. The line is no longer as well marked, but it is also less consequential. We cannot easily say what is constitutional and what is not, and, fortunately, little depends on our ability to do so.

What decisionmakers still must decide, though, is whether to treat particular rules as supreme, entrenched, and eligible for judicial review. The unbundled model indicates that they cannot answer those questions just by determining whether the rules in question are textual, structural, fundamental to American values, or the like. They will need to make some further substantive judgments, which is exactly what many theories of

19 See, for example, Strauss, The Living Constitution at 33-34 (cited in note 12); Bobbitt, Constitutional Fate at 29-37 (cited in note 12) (describing Justice Black's textualism as a response to a crisis precipitated by realist theories of judging); Ely, Democracy and Distrust at 43-69 (cited in note 7). 
constitutionality and of judicial review strive to avoid. That said, two points of potential comfort are worth highlighting.

First, despite the long, important, and understandable tradition of worrying about undisciplined judicial review, occasions requiring major exercises of subjective judgment on such questions are rare. Relatively few cases actually require judges to make new decisions about whether a given rule is properly enforced through judicial review. At this stage in the development of American law, most cases that come before courts are governed on this point by precedent, and that precedent is generally followed..$^{2}$ To be sure, some cases are not governed by precedent, and even cases that are so governed reflect the prior exercise of judgment, usually by some other court. But if the fear is that judges will be left at sea, it might help to realize that most of the time the waters are pretty well charted already.

Second, on those occasions when precedent is not clearly dispositive, no plausible theory of judicial review succeeds in eliminating the need for exercises of judgment. That being the case, it may be better to have an accurate understanding of the judicial task, even if that understanding leaves important questions open, rather than to rest on a theory that answers more questions but does so less accurately. ${ }^{21}$ To be sure, a sound theory that answered more questions about when and why judges should exercise judicial review would be more valuable than a

20 See Richard Primus, Limits of Interpretivism, 32 Harv J L \& Pub Pol 159, 16467, 172 (2009); Strauss, 63 U Chi L Rev at 883 (cited in note 15).

21 It is worth acknowledging the possibility that understanding a practice accurately is not always the practitioner's highest good. Perhaps a swimmer or a saxophonist might perform better without a precise understanding of all of her necessary physical movements, because operating with the precise understanding might cause her to focus on and worry about things that she would otherwise have done properly without conscious attention. Or perhaps the driver of a car will drive more safely with a slightly falsified understanding of his vehicle than if he truly understands everything the car can do. (I do not mean to take any position with respect to these specific examples; I mean only to suggest the nature of the concern.) If judging is such a practice, one might wonder whether American law would be better off if judges stuck to the idea that judicial review calls for them just to make their best assessments of formal authorities like constitutional text, rather than requiring them to consider in a more substantive way whether some rule should be judicially enforced. After all, the thought would run, the judges have been doing a reasonably good job up until now, even if they are operating with a slight misunderstanding of their activity; a more accurate understanding might either unnerve them (thus impeding their function) or liberate them (thus opening the door to mischief). I suppose that's possible. As a piece of scholarship, though, the function of this Article is to present a picture accurately, and perhaps thereby to do more good than harm, rather than to proceed on the assumption that clear-sighted understanding is on balance a dangerous thing. 
theory answering fewer of those questions. But it is not my ambition in this Article to develop a thorough and actionable justification for judicial review. Instead, I hope to lay bare some features of current practice that such a theory of judicial review should take into account. If the reality of constitutional practice is that the putative payoffs of constitutionality are not really driven by a set of formal criteria, we would improve our understanding by recognizing the fact.

One more framing assumption is worth specifying here. My claim-that the attributes of constitutionality behave more like sticks in a bundle than like a set of necessary bases and the payoffs that follow-is a claim about the existing practice of constitutional law in the United States. Each time I adduce evidence, as for example by pointing out that a given rule is treated as supreme or as enforceable through judicial review, I mean to report a feature of the practice as it exists. I do not offer deep justifications for these practices, and constitutional law as a whole might be improved by altering some of the practices I report. Perhaps some rule that is now treated as judicially enforceable should not be; perhaps some rule that is treated as changeable through ordinary legislation should be considered entrenched until overcome by some higher threshold for change. We have no reason, after all, to think that existing practice is perfect. That said, I presume throughout this Article that the existing practice of constitutional law in the United States is also not radically deficient. On that presumption, I investigate the system as it actually functions.

Not everyone shares that presumption. Some theorists see prevailing practice as a serious perversion of the constitutional system properly understood, such that the best course of action would be radical reform. ${ }^{22}$ If so, one such reform might be the bundling of constitutional attributes that I claim are best understood as separable sticks. In other words, some readers will be inclined to say that, if there are in fact a bunch of rules that are enforced through judicial review but not in the text or in the text but not treated as supreme law, that fact is regrettable, if not illegitimate. The appropriate response to our present reality, the argument might run, is not to build a constitutional theory on this unhappy mess but to insist on a more orderly system in

22 See, for example, Randy E. Barnett, Restoring the Lost Constitution: The Presumption of Liberty 354-57 (Princeton 2004); Richard A. Epstein, The Proper Scope of the Commerce Power, 73 Va L Rev 1387, 1387-88 (1987). 
which constitutionality has a clear set of bases and a clear set of payoffs, whether on the textual model or on one of the small-c alternatives.

My own suspicion, for what it is worth, is that this objection is both too pessimistic about the system that now operates and too optimistic about a preferred alternative. But I do not mean to pursue this line of disagreement to any great depth. For present purposes, suffice it to say that the analysis presented here is a characterization of American constitutional practice as we know it. That practice is imperfect, but it is not a failure. Understanding how it operates is at least as worthwhile an endeavor as speculating about some other system that seems unlikely to replace it.

In Part I of this Article, I illustrate the idea of constitutionality as a bundle of sticks by reference to what I have called the big-C approach. In Part II, I apply the same analysis to what I have called small-c approaches. Those approaches admit of greater complexity than the big-C approach, because they are not rooted in the simplifying idea that constitutional rules all share a single basis. But many small-c accounts still imagine constitutionality as a bundled status, with a broader set of bases driving a known set of payoffs.

The reality, I argue, is more complex still. The attributes of constitutionality combine in many different configurations, such that it is generally unwise to draw conclusions about a rule's status with respect to some of those attributes by reference to its status with respect to others. Accordingly, officials who must decide whether a given rule should be treated as supreme or entrenched or enforceable through judicial review should not frame their inquiry in terms of whether that rule is constitutional. After all, establishing the constitutionality of a rule will not answer the question that the decisionmaker must resolve, because no set of consequences reliably follows from a rule's being constitutional. To settle the actionable question, a decisionmaker must know something more. He must push beyond constitutionality.

\section{THE BIG-C BUNDLE}

\section{A. Four Sticks}

A simple form of the big-C vision can be understood as imagining constitutionality as a status with four elements. The first element is textuality. On this vision, constitutional rules are 
those-and only those-that are stated in the text of the written document we call the Constitution. The second element is supremacy. Constitutional rules are superior to other legal rules, such that a collision between a constitutional rule and any other legal rule must be resolved in favor of the constitutional rule. The third element is supermajoritarian entrenchment. Constitutional rules can be changed only through the process described in Article V; any nonconstitutional legal rule can be changed by ordinary legislation. Finally, the fourth element is eligibility for enforcement through judicial review. Courts have the authority to enforce constitutional rules-but only constitutional ruleswhen doing so requires nullifying enacted legislation. ${ }^{23}$

Two nods to nuance are here in order. First, textuality need not mean wooden literalism. ${ }^{24}$ Consider the distinction between the "hard textualism" that insists upon reading every word of applicable constitutional text closely and the "soft textualism" that accepts "reasonable" though nonliteral readings of constitutional text. ${ }^{25} \mathrm{~A}$ rule that is textual on either approach can be sufficiently textual to be big-C constitutional, so long as the text is the genuine source of the rule. Second, few sophisticated constitutional practitioners insist that this big-C picture fully and accurately captures American constitutionalism, either descriptively or normatively. Outside of confirmation hearings, many people freely recognize the nontextual bases of some constitutional rules, and even those generally inclined toward textualism usually acknowledge that a certain amount of nontextual constitutional law exists in practice. ${ }^{26}$ (For some, of course, that statement is made as a criticism of the practice that exists. ${ }^{27}$

23 It is tempting to recharacterize these four propositions as one unified idea: that the text of the written Constitution and only the text of the written Constitution is the supreme law. Article $V$ is part of the written Constitution, so the element of entrenchment might follow from the fact of textual supremacy. And though many have contested the point, many others read Article III to authorize judicial review. On that reading, all four elements of the big-C approach are present in the statement that the written Constitution is the supreme law. This articulation of the big-C idea as one unified whole presents that approach in what this Article would call its most fully bundled form.

24 See, for example, Caleb Nelson, What is Textualism?, $91 \mathrm{Va} \mathrm{L} \mathrm{Rev} \mathrm{347,} 348$ (2005) ("[N]o 'textualist' favors isolating [] language from its surrounding context.").

25 Richard Primus, Constitutional Expectations, 109 Mich L Rev 91, 97-98 (2010).

26 See, for example, Scalia, A Matter of Interpretation at 129, 139-40 (cited in note 6) (describing the role of stare decisis).

27 See Martin H. Redish and Matthew B. Arnould, Judicial Review, Constitutional Interpretation, and the Democratic Dilemma: Proposing a "Controlled Activism" Alternative, 64 Fla L Rev 1485, 1512 (2012) (describing nontextualism as a threat to "constitutional democracy"). 
With those qualifications understood, I want to call attention to three features of the picture I have sketched. First, the big-C vision shapes a good deal of thinking about constitutional law, even if most sophisticated practitioners regard it as incomplete. Most well-educated Americans who are not constitutional lawyers would probably supply something like this picture if asked to explain the role of constitutional law in American government. Certainly a great many law students enter their studies with something like this picture in mind, and many of them strive admirably to keep faith with that picture as they learn more and more about constitutional law. Even among theorists and practitioners who would say that some constitutional law lacks a textual basis, the big-C vision may supply a picture of constitutional law's normal case. Yes, the thought would run, there are instances in which other things are going on. But those instances are exceptions rather than the standard mode.

Second, the big-C vision I have sketched understands the four elements of constitutionality to travel together as a single bundle. A rule stated in the text is supreme and is entrenched and is eligible for judicial enforcement. A rule that cannot be changed except by amendment is supreme and is eligible for judicial enforcement and is grounded in the text. And so on.

Third, textuality is the basis of constitutional status, and the other three elements are payoffs. To be sure, identifying any one of the four elements as a property of a given rule establishes the rule's constitutional status. Only constitutional rules have these properties, so the presence of any of the four elements establishes constitutionality, which also means that it establishes the presence of the other three elements. But the fact that one can establish a rule's constitutionality by demonstrating any one of the four elements is evidentiary. As a justificatory matter, a rule is constitutional because it is written in the text. The other three elements are the payoffs that follow. Thus, the fact that a rule is enforced through judicial review indicates its constitutionality, and what that implicitly means is that the exercise of (legitimate) judicial review indicates that there is a textual justification for the rule.

This vision of constitutionality as a status with one basis (text) and three consistent payoffs (supremacy, entrenchment, judicial reviewability) has some considerable virtues. It is simple. It seems to capture well a canonical set of the virtues of 
written constitutionalism. ${ }^{28}$ It resonates with the widely held vision of the written Constitution as the authoritative basis of American government. ${ }^{29}$ It teaches that government officials are subject to a set of rules that they cannot alter by their own decree. And to the extent that it is internalized, it plays an important role in both enabling and constraining the practice of judicial review..$^{30}$ By presenting judicial review as the enforcement of a specified set of legitimately formulated rules, this big-C vision offers a clear and apparently mostly palatable explanation for why the work of elected officials must sometimes be set aside. At the same time, it cautions the judges against adventurism by telling them that their authority is limited by the content of those rules. To be sure, many judges understand that the judiciary can and does strike down laws that do not contravene any text in the written Constitution. But even so, the fact that the prevailing explanation for the legitimacy of judicial review requires appeal to an objective authority may help discourage judges from thinking of their own considered views as sufficient bases for declaring laws invalid.31

28 See, for example, Marbury v Madison, 5 US (1 Cranch) 137, 177-78 (1803) (articulating virtues of a written Constitution).

29 A community can be mistaken about its own practices. But other things being equal, it is a virtue for a theory of a social practice to be consistent with the selfunderstandings of the participants in that practice. See Clifford Geertz, The Interpretation of Cultures 14-15 (Basic Books 1973).

30 To be sure, one might count enabling judicial review as a liability: more than one important theorist has suggested that we would be better off without judicial review. See, for example, Jeremy Waldron, The Core of the Case against Judicial Review, 115 Yale L J 1346, 1353 (2006). But without taking the time necessary to argue the point all the way through, I will proceed on the premise that judicial review is, on balance, a net good within the system of American government. This is by no means to say that judicial review as it currently exists in the United States is the optimal form of judicial review. It is only to say, with full knowledge that the proposition would be very difficult to prove, that we are on balance better off with this institution as it exists than we would be if it did not exist at all.

31 The prevalence of the big-C idea executes these functions whether or not the substance of the idea accurately describes the operation of American constitutional law. The relevant effects on the attitudes and behaviors of judges and other officials-to whatever extent those effects materialize-follow from the fact that people articulate or subscribe to the big-C idea. In other words, the big-C idea need not be offered for the truth of the matter asserted. The assertion itself does a good deal of work, much of it desirable. To be sure, people who take the big-C idea seriously might balk at having it depicted as a helpful fable rather than a working theory of government, and at the extreme limit it is possible that the salutary effects of asserting the big-C picture would unravel if too many people came to think of it as a fable alone. But at present, no such danger seems to present itself. The big-C idea is alive and well. 
My project here, however, is to demonstrate a key respect in which the big-C vision thoroughly misdescribes the operative realities of American government. In practice, the different elements of constitutionality that big-C theory bundles together often travel separately. Many propositions that courts uncontroversially enforce through the power of judicial review are not derived from the Constitution's text. The text of the Constitution contains propositions that do not function as supreme law, despite never having been superseded by formal amendment. And many rules that have been treated as supreme law at some point in time have been changed by mechanisms other than the one that Article V deems necessary to overcome constitutional entrenchment.

I am not the first person to make most of the preceding claims. ${ }^{32}$ As noted above, few sophisticated American lawyers insist on big-C theory in its most inflexible form. And to the extent that practitioners and theorists of constitutional law recognize that the big-C picture is an oversimplification, a demonstration that constitutional practice departs from that picture will not be useful news. The aim of the analysis that follows, however, is not simply to show that the big-C conception is not a complete picture of mainstream constitutional practice. It is to show that the idea of constitutionality as a status with one basis (text) and three payoffs (supremacy, formal entrenchment, and judicial review) fails even as a rough approximation. Considered dispassionately, the big-C account is no more plausible as a description of constitutional practice - and perhaps considerably less plausible-than an account in which constitutional law is dominated by rules whose bases lie outside the text.

Perhaps the best way to unbundle the big-C picture of constitutionality is to give examples of well-accepted rules that have some but not others of the four properties that the big-C picture bundles together. So consider Figure 1, located at page 1105. This four-by-four grid has sixteen boxes representing all the ways in which a rule might have one of the elements in the

32 See, for example, Strauss, The Living Constitution at 115-17 (cited in note 12); Charles L. Black Jr, Structure and Relationship in Constitutional Law 11, 29-32 (LSU 1969) (arguing for nontextual sources of constitutional law); Tiedeman, The Unwritten Constitution at 155 (cited in note 11); Bruce Ackerman, The Living Constitution, 120 Harv L Rev 1737, 1741-43 (2007) (describing processes of constitutional change other than Article V); Grey, 27 Stan L Rev at 706-10 (cited in note 7) (arguing for nontextual sources of constitutional law); Llewellyn, 34 Colum L Rev at 3-4 (cited in note 16). 
big-C bundle but lack one of the other elements, and the boxes are populated with examples.

For Figure 1 and other parts of the present claim to be persuasive, though, my argument must overcome an obstacle regarding the selection of rules that are to count as examples. Suppose that in the course of arguing that nontextual rules are pervasive in constitutional law, I offer rules about commandeering, state sovereign immunity, and abortion as examples of nontextual constitutional rules. Someone who wanted to resist my perspective - that is, someone who wanted to argue that nontextual rules are rare or nonexistent within constitutional lawmight contest the legitimacy of those examples in either of two ways. First, he might pronounce some or all of those rules invalid and thus not really admissible as evidence of constitutional law properly understood. This possibility arises from the persistent fact that many (putative) constitutional rules are of contested validity. To the extent that we cannot agree on what rules count as the rules of constitutional law, it will be hard to convince each other of claims about the set of constitutional rules. Second, even if a critic of my argument agreed that the rules about commandeering or abortion or state sovereign immunity are valid examples of constitutional rules, he might dispute my characterization of those rules as nontextual. People see different things in the same texts, after all. If we cannot agree about whether a given rule is present in the text, we will be less able to convince each other that textuality is, or is not, a necessary (or nearly necessary) property of constitutional rules.

I doubt that these obstacles can be overcome to the satisfaction of every reader. To be fully persuasive, my argument would need to make use of a set of examples that everyone agrees are examples of valid constitutional rules, and it would also require broad agreement about whether each rule discussed was in fact textual, supreme, formally entrenched, and subject to judicial review. The community of constitutional practitioners is too diverse in its views for full consensus to be feasible on these points. It may be possible, however, to offer an analysis that rests on enough common ground to persuade many and perhaps most readers that the four sticks in the big-C bundle can be pulled apart. To that end, I adhere to two methodological principles.

First, to the greatest extent possible, I will discuss only rules whose validity is broadly accepted within the world of 
constitutional practice. That does not mean that I will avoid discussing rules with which some people disagree. Someone doubts the validity of just about every rule, including the rule authorizing the existence of the Federal Reserve Bank ${ }^{33}$ and the rule forbidding the racial segregation of a state's public schools. ${ }^{34}$ It means, rather, that I will limit myself to rules that are relied on as a matter of course in the practice of constitutional law, and will avoid rules whose validity is the subject of significant ongoing contest. If I confine my analysis to rules of that kind, then critics who would respond by denying that the rules I adduce are valid illustrations of American constitutional law will be in the position of offering a radical critique of the practice, rather than of contesting my description of the practice as it exists.

Second, I will articulate criteria for classifying rules as textual, supreme, formally entrenched, or judicially reviewable. Some of these characterizations are slippery because they turn on matters of contested judgment. Sometimes we differ in our assessment of phenomena we observe: different people read texts differently, so a rule that seems textual to one person might seem nontextual to someone else. In other instances, clear right answers about whether rules exhibit these characteristics are elusive because they rest on predictions about the conduct of actors in the system. To say that a rule is entrenched by the terms of Article $V$, for example, it is not for present purposes sufficient to point out that the rule is a constitutional rule and that the Constitution can only be amended through Article V. To make the case that way would simply be to report the big-C theory, rather than to demonstrate something about how American constitutional practices actually operate. To show that a rule is Article $\mathrm{V}$ entrenched as an operative matter, one would have to show that changing the rule would in practice require an Article $\mathrm{V}$ amendment. As I describe more thoroughly below, that might be a hard demonstration to make. ${ }^{35}$

33 See Ron Paul, End the Fed 18-31 (Grand Central 2009) (arguing that the Federal Reserve is unconstitutional). But see McCulloch v Maryland, 17 US (4 Wheat) 316, 324-26 (1819) (upholding Congress's creation of the Bank of the United States).

34 See Adrian Vermeule, Judging under Uncertainty: An Institutional Theory of Legal Interpretation 280 (Harvard 2006) (arguing that Brown was wrongly decided).

35 Articulating these methods should clarify what the classifications mean as used here. To be sure, no reader is compelled to accept the choices these methods reflect. That said, these explanations should sharpen the idea of unbundled constitutionality that is offered in this Article because they will help elucidate a view of the relationships among these features of constitutional rules. And if the slipperiness and uncertainty involved in these classifications make it hard to establish that each example offered really does 
Here, then, are explanations of what it means, for purposes of the present analysis, to say that as a matter of operative practice a rule is or is not textual, or supreme, or Article V entrenched, or judicially reviewable. The discussions of supremacy and judicial review are relatively brief; those of textuality and entrenchment require more complexity.

\section{Textuality.}

Any claim that a given rule is or is not stated in the Constitution's text must reckon with the fact that different people understand that text to carry different meanings. In many cases, whether the text embodies a particular rule is a matter of legitimate controversy. But the lesson here is not that differentiating between textual and nontextual rules is a hopeless enterprise. It is that one should be prepared to see nuance in the subject matter when approaching the categorization.

One good step in that direction is to understand textuality as a dimensional category rather than a binary one. Rules may be more and less grounded in the text rather than being fully textual or fully not. With that perspective in mind, the set of rules that properly socialized practitioners of American law would uncontroversially identify as constitutional rules can be imagined to lie along a continuum of textuality, and that continuum can be illustrated as follows:

(1) The rule is plainly stated in the text. (Example: Every state gets two senators.) ${ }^{36}$

(2) The rule is fairly implied by the text. (Example: Congress can create an Air Force.) ${ }^{37}$

(3) The rule is not stated in the text, but it is associated with a particular clause, and we have an official story explaining why that clause justifies the rule despite its

demonstrate a certain combination of constitutional characteristics, the exercise of working through the examples should still make the fully bundled big-C picture hard to maintain simply by highlighting how hard it is to say with confidence that a particular rule is textual, supreme, formally entrenched, and judicially reviewable. The picture of big-C bundling requires one to be able to make that judgment cleanly about every constitutional rule.

36 US Const Amend XVII.

37 US Const Art I, § 8, cl 12 (authorizing Congress to "raise and support Armies"). 
wording. (Example: The state of Michigan may not abridge the freedom of speech.) $)^{38}$

(4) The rule is not stated in the text, but it is associated with a particular clause, and we have an official story explaining why that clause entails the proposition despite its wording, and the official story strains plausibility, but we go with it anyway. (Example: Congress may not segregate public schools.) $)^{39}$

(5) The rule is not stated in the text, but it is associated with a particular clause, and we have no story at all explaining why the clause entails the proposition despite its wording, but we seem not to mind or even to notice. (Example: The president may not abridge the freedom of speech. $)^{40}$

(6) The proposition is not stated in the text, but it is associated with a particular clause, and we acknowledge that the wording of the clause does not entail the proposition. (Example: Congress may not commandeer state executive officials.) ${ }^{41}$

38 See, for example, Locke v Davey, 540 US 712, 718 (2004) (treating the substantive provisions of the First Amendment as incorporated against the states through the Due Process Clause of the Fourteenth).

39 See Bolling $v$ Sharpe, 347 US 497, $498-99$ (1954). See also Richard A. Primus, Bolling Alone, 104 Colum L Rev 975, 976 (2004) (explaining and criticizing the idea that the Equal Protection Clause of the Fourteenth Amendment is incorporated against the federal government through the Due Process Clause of the Fifth Amendment).

40 See, for example, Federal Communications Commission v Fox Television Stations, Inc, 132 S Ct 2307, 2312 (2012). The idea that the First Amendment runs against the executive branch is not controversial. But the text of the First Amendment is addressed to "Congress." Many words in the Constitution are subject to multiple interpretations, but if pressed to identify something that the word "Congress" in the Constitution should not be read to mean, "President" seems like a safe choice. Unlike the extension of First Amendment norms to cover states, which is officially explained by the doctrine of incorporation, no official story exists to explain why a text written as a limitation on the power of Congress also works a limitation on the power of a different branch of the federal government. Much the same could be said of the idea that the guarantees of the First Amendment run against the federal courts. See, for example, Bernard $v$ Gulf Oil Co, 619 F2d 459, 466-67 (5th Cir 1980) (invalidating the district court's gag order as a violation of the First Amendment's guarantee of the freedom of speech). The judiciary, like the president, is not the Congress.

41 See Printz v United States, 521 US 898, 905 (1997) ("Because there is no constitutional text speaking to this precise question, the answer to the CLEOs' challenge must 
(7) The proposition is not even associated with any particular clause in the text. (Example: No state may unilaterally secede from the Union. ${ }^{42}$

The degrees of textuality that I have here assigned to these constitutional rules are the ones that seem to me most plausible as a reader of the Constitution. Other people will likely argue for somewhat different classifications. Because people are drawn to varying interpretations of texts, reasonable people can disagree about where along the continuum a given proposition falls. For example, I have identified the proposition that Congress may not segregate public schools as one that is associated with a clause in the Constitution by virtue of a largely implausible official story. That story, of course, is that the text of the Due Process Clause of the Fifth Amendment incorporates the content of the Fourteenth Amendment's Equal Protection Clause. My reasons for skepticism about that story as an account of reading the text are conventional. ${ }^{43}$ Nonetheless, I recognize that other interpreters might find that reading of the Fifth Amendment's text more plausible than I do, 44 in which case they might classify this proposition as closer to (3) above than to (4). I do not think, however, that any reasonable argument can present all seven of

be sought in historical understanding and practice, in the structure of the Constitution, and in the jurisprudence of this Court."). Note, however, that constitutional discourse's tendency to seek textual homes for doctrines, see note 45 , has fostered subsequent reformulations of the anticommandeering principle under which the rule might be understood to be an interpretation of the Necessary and Proper Clause. See, for example, Ilya Somin, A Mandate for Mandates: Is the Individual Health Insurance Case a Slippery Slope?, 75 L \& Contemp Probs 75, 89 \& $n 64$ (2012) (presenting the holding of Printz as an interpretation of the term "proper" in the Necessary and Proper Clause); Transcript of Oral Argument, Department of Health and Human Services v Florida, No 11-398, *26-27 (US Mar 27, 2012) (available on Westlaw at 2012 WL 1017220) (Scalia) (characterizing the holdings of Printz and New York $v$ United States as interpretations of the term "proper" in the Necessary and Proper Clause).

42 As the old joke has it, the legal authority for this constitutional proposition is the case of Lee $v$ Grant. See, for example, Josh Chafetz, Book Review, Multiplicity in Federalism and the Separation of Powers, 120 Yale L J 1084, 1097 n 74-75 (2011).

43 See, for example, Ely, Democracy and Distrust at 32 (cited in note 7 ) (describing the reverse incorporation doctrine as "gibberish"). See also Primus, 104 Colum L Rev at $977 \mathrm{n} 7$ (cited in note 39) (collecting criticism of the doctrine).

44 See, for example, Lawrence Lessig, Understanding Changed Readings: Fidelity and Theory, 47 Stan L Rev 395, 408-10 (1995) (arguing that Bolling correctly recognized that Reconstruction had changed the meaning of "Due Process"). 
these constitutional rules as clearly stated in or even as fairly implied by the text itself. ${ }^{45}$

In demonstrating that many nontextual rules are operatively supreme, entrenched, or judicially enforceable, I will use only examples that seem to me to fall in categories (5), (6), and (7). That is so even though rules in category (4) and perhaps even category (3) are also probably best understood as rooted in something other than the text. ${ }^{46}$ By restricting myself to the yet more clearly nontextual rules in categories (5), (6), and (7), I hope to reduce the incidence of objections that proceed by contesting my characterization of rules as nontextual. And to the degree that I am right to regard rules in categories (3) and (4) as nontextual too, readers should infer that the degree to which textuality can be separated from supremacy, formal entrenchment, and judicial review is substantially greater than the set of examples offered here might suggest.

45 This statement is true as I write it. But it may be true only contingently, under the circumstances of 2013. A large part of the process of constitutional change is about shifting expectations that make it plausible to read a text differently at different times. Part of the job description of good constitutional lawyers is to find ways to move propositions down this continuum, taking norms that seem nontextual and finding ways to read the text so as to encompass them. Similarly, and precisely because of the background power of the big- $\mathrm{C}$ vision, the pressure of a concrete need for judicial action may prompt a court to create an official association between a proposition and a clause where there was none before. Above, I say that the proposition that no state may secede from the Union is not even associated with any particular clause in the Constitution. But a court that was actually called upon to review the constitutionality of a state statute announcing that state's secession from the Union might well read any of a number of clauses to prohibit the secession. After that date, the proposition that no state may secede would in fact be associated with a clause, so it would no longer be an example of my seventh category. Which category the proposition would then represent would depend upon what explanation the court gave of the link between the clause and the proposition, as well as whether the audience of constitutional lawyers-then and later-found the link plausible as a matter of reading the text. I cannot say, therefore, that the mapping I provide above will always seem sensible to conversant constitutional lawyers. But it is likely that, at any given time, the set of propositions that are uncontroversially regarded as constitutional will be arranged along this continuum.

46 My own view, for what it is worth, is that the text of the Constitution cannot reasonably be read to direct either the rule that the State of Michigan may not abridge the freedom of speech or the rule that Congress may not segregate public schools by race, even on a "soft textualist" understanding of what the text might say. The better understanding of the relationship of these rules to the text is that the rule arises from sources outside the text and is then associated with a portion of the text that addresses some related subject. That process of association might be described as a species of textualism, but if so, it is not what the big-C conception means by textualism because the text is not operating as the basis of the rule's constitutional status. See Primus, 32 Harv J L \& Pub Pol at 167 (cited in note 20) ('If textualism has a core, it is the proposition that the text of the law has meaning and authority independent of what the judges have said and done."). 
2. Supremacy.

In this analysis, the statement that a rule operates as supreme law means that either or both of the following two things is true:

(1) Actions violating that rule are reliably nullified, punished, or redressed by some institutional authority whose actions in this regard are not subject to override by some other institutional decisionmaker. ${ }^{47}$

(2) Nobody with the capacity to violate the rule attempts to do so, even when it would be in their interests, because all such actors regard themselves as being under the authority of a rule.

Rules that are regularly enforced by courts exercising the power of judicial review exemplify the first condition. If the government tried to censor this Article because it disagreed with the views expressed here, any court in the land would issue an injunction against the censorship. A good example of a rule that is (or was) supreme on the strength of the second condition was the rule, prior to 1940 , that presidents should retire after serving two terms. Between George Washington and Franklin Roosevelt, presidents seem to have considered themselves obligated to step aside at the end of their second terms, and informed analysts accordingly described the two-term limit as a rule of constitutional law. ${ }^{48}$

As the preceding example demonstrates, a determined constitutional entrepreneur can sometimes overcome or eliminate a rule of supreme law by declining to recognize its authority and getting away with it. If someone denies the authority of a rule that previous people in the same position felt themselves governed by, and if no other actor steps in to enforce the rule, the rule is no longer supreme because neither of the two conditions any longer obtains. President Roosevelt's successful breach of the norm indicated that the rule did not in fact operate as

47 By an "institutional decisionmaker," I mean a court, a legislature, or some other form of regularly operating body. I mean to exclude episodic decisionmaking processes like those involved in adopting formal constitutional amendments.

48 See, for example, William Bennett Munro, The Makers of the Unwritten Constitution 17-18 (Macmillan 1930); Tiedeman, The Unwritten Constitution at 51-53 (cited in note 11); Llewellyn, 34 Colum L Rev at 14 (cited in note 16). 
supreme law. Note, however, that President Roosevelt's innovation demonstrated only that the two-term limit did not function as supreme law in 1940, when Roosevelt ran for his third term. The fact that the limit was not supreme law in 1940 does not tell us whether it operated as supreme law in the nineteenth and early twentieth centuries. Whether the norm operated as supreme law at those times depends on the operative practices of those times, and it does seem that people treated the two-term limit as supreme law before President Roosevelt challenged the norm.

Note that these two conditions for a rule's operating as supreme law are independent of each other. Sometimes both exist at the same time: any court would block governmental censorship of this Article, but nobody expects such judicial intervention to be necessary, because government officials generally recognize that trying to censor speech would be a violation of authoritative rules and do not try to exercise censorial powers even when they dearly wish that some form of unwelcome speech would go away. That said, either of the two conditions can exist without the other, and either one is sufficient to demonstrate that a rule is operating as supreme law.

\section{Article $\mathrm{V}$ entrenchment.}

Article $\mathrm{V}$ provides that the Constitution can only be changed by a formal supermajoritarian process requiring action by Congress and ratification by three-fourths of the states. ${ }^{49}$ Most practitioners recognize, however, that the operative rules of constitutional law can also be changed by other mechanisms, prominently including a majority vote of the Supreme Court. Several theorists have persuasively argued that most change to American constitutional law over the course of the last two hundred years has come without Article $\mathrm{V}$ amendments. ${ }^{50}$ In practice, therefore, many rules that the bundled big-C vision imagines as Article $V$ entrenched have turned out not to be so.51 To be sure, one might contend that constitutional change without Article $\mathrm{V}$ amendment is illegitimate or, more softly, that it works

49 US Const Art V.

50 See, for example, Bruce Ackerman, 1 We the People: Foundations 44-57 (Belknap 1991); David A. Strauss, The Irrelevance of Constitutional Amendments, 114 Harv L Rev 1457, 1457-59 (2001); Llewellyn, 34 Colum L Rev at 21-23 (cited in note 16).

51 One could also characterize President Roosevelt's running for and winning a third term as a change to a constitutional rule through a mechanism other than Article $V$. 
changes only in "constitutional doctrine" or "constitutional law," each conceived as something different from the Constitution itself.52 For the reasons previously explained, however, I will move past these scruples. As always in this Article, the focus is on how the constitutional system actually functions. ${ }^{53}$

To decide that a rule is Article $\mathrm{V}$ entrenched in practice, one would have to conclude that there is no process less demanding than Article $\mathrm{V}$ amendment that could change the rule. That is a difficult judgment to render in advance about most constitutional rules, especially if one internalizes deeply the point that farreaching constitutional change has in fact occurred without Article $\mathrm{V}$ amendment, including change that people situated ex ante might have thought could never occur without such amendments. Prior to the twentieth century, well-socialized American lawyers might have thought that, unless the Constitution were amended, constitutional law could not possibly authorize Congress to enact pervasive economic regulations, to delegate broad power to administrative agencies, or to prohibit racial discrimination in privately owned businesses. All those things turned out to be possible without amendments. The Eighteenth Amendment testifies eloquently to one age's conviction that Article $\mathrm{V}$ was the means for accomplishing what another age could accomplish by federal statute, were it inclined to do so. In the twenty-first century, when the Controlled Substances Act is valid Commerce Clause legislation, ${ }^{54}$ there is little reason to doubt that a federal statute banning the sale of alcohol would be similarly upheld.

Perhaps it is unwise, therefore, to conclude that any rule is Article $\mathrm{V}$ entrenched for all time. If enough members of the decisionmaking class come to view an issue differently in the future from the way it is understood now, constitutional change might be accomplished by other means. When prevailing opinion moves far enough to ratify an Article $\mathrm{V}$ amendment, the same climate of opinion tends to foster changed intuitions about how to read the existing constitutional text. By the time amendment

52 See, for example, Levinson, Constitutional Faith at 30-37 (cited in note 6) (describing this view).

53 Within that framework, the idea of a metaphysically correct constitutional rule that differs from operative doctrine is in one respect consequential: sometimes that idea motivates practitioners, some of whom might be judges, to work a change in the operative law.

54 See Gonzales v Raich, 545 US 1, 22 (2005). 
is feasible, therefore, it may no longer be necessary. ${ }^{55}$ Consider, as an example, the way that sex equality emerged as a broadly accepted tenet of equal protection doctrine at roughly the same time that the proposed Equal Rights Amendment was close to ratification. ${ }^{66}$ The switch in time of 1937 provides other canonical examples, including a change in the scope of Congress's enumerated powers ${ }^{57}$ and a change in the meaning of the property rights protected by the Fifth and Fourteenth Amendments. ${ }^{58}$

The categorization of a given rule as Article $\mathrm{V}$ entrenched is therefore better understood as a judgment about the foreseeable future than as a judgment about the rule per se. In practice, Article $\mathrm{V}$ states the rule of entrenchment for those rules that, at the relevant time, are more easily changed by amendment than otherwise. Whether Article $V$ is an easy or hard route to change relative to other possible mechanisms will vary over time with the state of opinion in the decisionmaking class. Sometimes it is easier to get the Court to change than it is to pass an amendment, and sometimes the opposite is true. Understood in this light, describing a rule as Article $\mathrm{V}$ entrenched means that we do not foresee the Supreme Court's reading the Constitution in a way that alters the existing rule, nor do we foresee the Court's acquiescing if the other branches struck out in that direction.

It is tempting to qualify the foregoing framework with the following proviso: for rules where the text is especially clear, Article $\mathrm{V}$ amendment is the only possible route to change. It is hard to imagine, for example, that any mechanism other than Article $\mathrm{V}$ could change the length of the president's term from four years to three. That said, attention to historical examples of unanticipated change should encourage humility even with respect to a prediction like this one. Part of what makes it easy to assume that the president's term could not change without an Article $\mathrm{V}$ amendment is that the issue of presidential term length is not, in our experience, a matter of controversy. If large numbers of American officials came to believe that the four-year

55 See, for example, Primus, 109 Mich L Rev at 99-100 (cited in note 25); Strauss, 114 Harv L Rev at 1462-63 (cited in note 50).

56 See Frontiero $v$ Richardson, 411 US 677, 687-88 (1973) (discussing the relationship between questions of sex equality under the Fourteenth Amendment and the thenpending Equal Rights Amendment).

57 See NLRB v Jones \& Laughlin Steel Corp, 301 US 1, 30 (1937) (upholding provisions of the National Labor Relations Act as valid exercises of Congress's commerce power).

58 See West Coast Hotel Co v Parrish, 300 US 379, 391, 398-99 (1937) (upholding minimum wage legislation). 
term was seriously flawed, pressure might mount to find ways to read the Constitution to solve the problem. In the absence of such pressure, the idea that the Constitution could be read to permit something other than a four-year term is likely to seem absurd. Maybe it would seem absurd under any circumstances; if I had to guess, I would hazard that the Republic will fall before the length of the president's term changes without a formal amendment. But assuming that the substantive issue will not be controversial in our lifetimes, we may never know whether the text could be read differently. ${ }^{69}$ The point, in any case, is this:

59 We may never know, for example, if it could be read like this: Article II, Section 1 says that the president ". . shall hold his Office during the Term of four Years." We have read "during the Term of four Years" to mean "for a four-year term." But as a matter of ordinary language, something that happens "during" a specified time need not occupy the entirety of the time specified. Thanksgiving happens "during" November, but November is a longer period of time than Thanksgiving. So if the president were to serve a three-year term, he would hold his office "during the Term of four Years"-just not for the entirety of that period. Once this possible reading is in view, we should notice that the Constitution's language describing the term lengths of other elected officials is different from that of Article II. Article I specifies that members of the House of Representatives shall be chosen "every second Year." Axticle II does not provide that presidential elections shall be held "every fourth year," though obviously it could, so the difference suggests that the timetable for presidential elections is more variable than that for House elections. And with respect to the Senate, both Article I and the Seventeenth Amendment provide that Senators shall be elected "for six years." That straightforward formulation indicates that the Constitution knows how to specify a concrete term length when it wants to do so. Article II could have said that the president would be elected "for four years," but it doesn't. It sets a limit by saying that the term shall be "during" four years. Presumably, therefore, the president's length of service could be set at something shorter than four years, say by the terms of a statute passed under Congress's power to make laws necessary and proper for carrying into execution the powers vested in the federal government.

In the world of constitutional interpretation in the year 2013, the preceding argument is completely implausible (as would be any other argument for a presidential term lasting more or less than four years). We all know that "during the Term of four Years" in Article II means "for four years." And we aren't wrong. What we do not and cannot know is whether our successors would share our conviction on that point, if somehow they came to believe urgently that the good of the Republic required presidents to serve shorter terms. Under that pressure, they might sincerely understand the text differently from us-whether in accordance with the interpretation I have sketched above or in some other way that I do not presently imagine, as we today accept readings of the Constitution that would have been implausible to our predecessors generations ago.

My willingness to guess that the length of the presidential term will not change without formal amendment thus does not rely only on the text of Article II. It also relies on the fact of visible, salient, consistent practice. We all have lived experience of the four-year cycle, and we all know that it goes all the way back to the beginning. Accordingly, everyone would recognize a new textual interpretation as a change. And given how thoroughly and unambiguously Americans are aware that the four-year term has been consistent from the beginning, everyone would probably understand that change as a new departure rather than as the recovery of a correct but now-lost reading. That the 
given how many once-absurd readings of the Constitution have become judicial doctrine, respect for the adaptability of our successors should prompt us to qualify even our most confident intuitions about what the text could not possibly accommodate.

\section{Judicial review.}

If the judiciary has in fact enforced some rule with an exercise of judicial review, I will take it as established that that rule can be adduced as an example of something to which judicial review attaches. To reduce controversy, I will draw examples from exercises of judicial review whose legitimacy is not the subject of heated current debate.

For all the reasons that negatives are hard to prove, it is more difficult to demonstrate that a particular rule is not enforceable through judicial review. Even if the Supreme Court declares an issue not fit for judicial resolution today, a somewhat different presentation of the issue might provoke the Court to assert itself tomorrow. ${ }^{60}$ But with that caveat duly noted, I will take the Court's statements about nonjusticiability as guides to what competent practitioners should reasonably understand about the practice that currently exists. When I go beyond that boundary in characterizing something as nonjusticiable, I will try to limit myself to strongly supportable intuitions and to note the limits of what can be predicted.

\section{B. Unbundling}

The next page contains a four-by-four table depicting all of the possible ways in which text, supremacy, Article V entrenchment, and judicial review can be pulled apart. Some of the boxes in the table require little elucidation, and others call for considerably more. In what follows, I discuss the possible combinations in order, beginning in the top-left corner and moving down the columns, skipping the four boxes that are not applicable for obvious logical reasons. The point of the exercise is to show that-

four-year term is visible, salient, and has been consistently practiced would thus make it more difficult for constitutional entrepreneurs to propose alternatives to the relevant text of Article II than to propose alternative readings of other texts that are no more "clear" as a matter of pure textual interpretation.

60 For a canonical example, contrast Colegrove v Green, 328 US 549, 552 (1946) (declaring nonjusticiable a challenge to an electoral districting plan), with Baker $v$ Carr, 369 US 186, 208-10 (1962) (declaring such a challenge justiciable when presented as an equal protection claim rather than a Guarantee Clause claim). 
with one exception-a rule with one or more of these characteristics might or might not have any of the others.

FiguRE 1

\begin{tabular}{|c|c|c|c|c|}
\hline & In the Text & Supreme Law & $\begin{array}{l}\text { Article V } \\
\text { Entrenched }\end{array}$ & $\begin{array}{l}\text { Judicial } \\
\text { Review } \\
\end{array}$ \\
\hline $\begin{array}{l}\text { But Not in the } \\
\text { Text }\end{array}$ & $\mathrm{n} / \mathbf{a}$ & $\begin{array}{l}\text {-Congress may } \\
\text { not move } \\
\text { Election Day } \\
\text { for partisan } \\
\text { reasons. } \\
\text {-States must } \\
\text { permit popular } \\
\text { voting in } \\
\text { presidential } \\
\text { elections. }\end{array}$ & $\begin{array}{l}\text {-The president } \\
\text { may not order } \\
\text { military } \\
\text { personnel to } \\
\text { attend Catholic } \\
\text { Mass just } \\
\text { before battle. }\end{array}$ & $\begin{array}{l}\text { - Congress may } \\
\text { not segregate } \\
\text { schools by race. } \\
\text {-States are } \\
\text { immune from } \\
\text { damage actions } \\
\text { brought by } \\
\text { their own } \\
\text { citizens. }\end{array}$ \\
\hline $\begin{array}{l}\text { But Not } \\
\text { Supreme Law }\end{array}$ & $\begin{array}{l}\text {-Mandatory } \\
\text { jury trial in } \\
\text { criminal cases. } \\
\text { - Six-year } \\
\text { Senate term } \\
\text { (for new } \\
\text { states). } \\
\text { - Presidential } \\
\text { presentment of } \\
\text { proposed } \\
\text { amendments. }\end{array}$ & $\mathbf{n} / \mathbf{a}$ & $\begin{array}{l}\text {-Mandatory } \\
\text { jury trial in } \\
\text { criminal cases. } \\
\text { 6-year Senate } \\
\text { term (for new } \\
\text { states). } \\
\text {-Presidential } \\
\text { presentment of } \\
\text { proposed } \\
\text { amendments. }\end{array}$ & $\begin{array}{l}\text {-Exclusionary } \\
\text { rule. } \\
\text { - Dormant } \\
\text { commerce } \\
\text { restrictions. } \\
\text { - Constitutional } \\
\text { default rules } \\
\text { generally. }\end{array}$ \\
\hline $\begin{array}{l}\text { But } \\
\text { Changeable } \\
\text { without Art V } \\
\text { Amendment }\end{array}$ & $\begin{array}{l}\text { None } \\
\text { (actually } \\
\text { bundled). }\end{array}$ & $\begin{array}{l}\text {-Holdings of } \\
\text { Roe } v \text { Wade } \\
\text { and Citizens } \\
\text { United } v \text { FEC. } \\
\text {-Two-term } \\
\text { presidential } \\
\text { limit prior to } \\
1940 \text {. }\end{array}$ & $\mathrm{n} / \mathbf{a}$ & $\begin{array}{l}\text {-Constitutional } \\
\text { default rules. } \\
\text {-Holdings of } \\
\text { Roe } v \text { Wade } \\
\text { and Citizens } \\
\text { United v FEC. }\end{array}$ \\
\hline $\begin{array}{l}\text { But Not } \\
\text { Enforceable } \\
\text { through } \\
\text { Judicial } \\
\text { Review }\end{array}$ & $\begin{array}{l}\bullet \text { Political } \\
\text { questions. }\end{array}$ & $\begin{array}{l}\text {-Two-term } \\
\text { presidential } \\
\text { limit prior to } \\
1940 \text {. } \\
\text { - Supreme } \\
\text { Court has nine } \\
\text { members. }\end{array}$ & $\begin{array}{l}\text { Supreme } \\
\text { Court has nine } \\
\text { members. }\end{array}$ & $\mathbf{n} / \mathbf{a}$ \\
\hline
\end{tabular}

1. Text without supremacy.

We start at one of the hardest points, so the explanation of this box will take considerably more space than the explanation of any other box. 
Many earlier commentators have noticed that a great deal of American constitutional law rests on nontextual foundations. ${ }^{61}$ But most of them have maintained that the text is simply underinclusive of the operative content of constitutional law. On that view, constitutional law contains things that are not in the text, but everything in the text is respected as constitutional law. ${ }^{62}$

The idea that every rule stated in the text of the Constitution is a constitutional rule makes sense at the level of labels. It is entirely ordinary to use the term "constitutional" to describe any rule stated in the Constitution. It does not follow, however, that all rules stated in the text enjoy the payoffs that might flow from constitutional status. As is germane to the box under discussion, several rules stated in the constitutional text are not treated as supreme law. They are routinely ignored and violated.

Before giving examples of these nonsupreme (and indeed non-operative) rules, it is worth noting again that my view relies on a willingness to limit the range of meanings that can be attributed to a text. It is possible to maintain that every rule contained in a text is followed, so long as one is willing to read the text in whatever nonstandard way is necessary to make that text match prevailing practice. Just as the community of constitutional interpreters has found creative ways to locate previously nontextual ideas within the constitutional text, it can find ways to read out of the text any rules that do not conform to accepted constitutional law. ${ }^{\text {B }}$

It is a normal dynamic of American constitutional interpretation that people struggle to close the gap between the text and the set of rules that are recognized as entitled to supremacy, entrenchment, and judicial review. ${ }^{64}$ Pressure to generate readings

61 See Strauss, The Living Constitution at 34-35 (cited in note 12); Black, Structure and Relationship at 11, 29-32 (cited in note 32); Grey, 27 Stan L Rev at 706-07 (cited in note 7); Llewellyn, 34 Colum $L$ Rev at 3-5 (cited in note 16).

62 See, for example, Grey, 37 Stan L Rev at 1-3 (cited in note 8) (identifying nontextualists as "supplementers" because their position is that constitutional authority includes more than just the text).

63 See generally Pamela S. Karlan and Daniel R. Ortiz, Constitutional Farce, in William N. Eskridge Jr and Sanford Levinson, eds, Constitutional Stupidities, Constitutional Tragedies 180 (NYU 1998) (arguing that the conventions of constitutional argument are sufficiently flexible so that it is always possible to articulate an interpretation that would avoid an unwanted outcome).

64 See Michael C. Dorf, How the Written Constitution Crowds Out the Extraconstitutional Rule of Recognition, in Matthew D. Adler and Kenneth Einar Himma, eds, The Rule of Recognition and the U.S. Constitution 69, 69-83, 86-87 (Oxford 2009) (discussing 
under which the text contains no ignored rules starts to build as soon as people realize that we presently lack canonical explanations for why rules that an untutored reader might (easily) find in the text are really not there at all. My claim, then, is simply that competent readers of English who do not know the practice that the text is supposed to match would find in the text several rules that are not followed in practice.

Here are three examples.

1) Trial by jury in criminal trials. Article III provides as follows: "The Trial of all Crimes, except in Cases of Impeachment, shall be by Jury . . . ."65 In practice, many criminal trials in Article III courts take place without juries. To be sure, defendants may demand jury trials if they wish.66 But defendants are also routinely permitted to choose bench trials if they would prefer to be tried by judges. ${ }^{67}$ The text of Article III, however, is written in inflexible terms: "The Trial of all Crimes . . . shall be by Jury."

It is not hard to understand why practice departs from the text on this point. We understand jury trial mostly as a measure for the protection of defendants, and nothing strikes us as bizarre or upsetting about a bench trial if the defendant prefers to proceed that way. State courts routinely hold bench trials, so our general sense of what makes a trial a trial accommodates trial by judge as well as trial by jury. To insist on a jury trial over a defendant's objection might seem otiose, not to mention cumbersome and expensive. To be sure, one could imagine a regime that regarded jury trial as sufficiently important as to be nonwaivable by the defendant. Indeed, the untutored reader of Article III would think that the United States Constitution establishes such a regime. But it seems not to. For generations, Article III courts have held bench trials with the consent of defendants. That dominant practice has shaped what I have elsewhere called our constitutional expectations.68 And as often happens, our constitutional expectations have the power to divert our attention from the words in the text.

the tendency to shoehorn nontextual norms into arguments about the Constitution's text).

65 US Const Art III, § 2, cl 3.

66 See, for example, United States v Gaudin, 515 US 506, 511 (1995).

67 See, for example, United States v Hanjuan Jin, 833 F Supp 2d 977, 980 (ND Ill 2012) (bench trial); United States $v$ Weaks, 840 F Supp 2d 12, 17 (DDC 2012) (bench trial).

68 Primus, 109 Mich L Rev at 93-94 (cited in note 25). 
The words are still there, of course, in every printed copy of the Constitution. It should therefore be a straightforward matter to say that the text of the Constitution announces, as a rule, that criminal trials in Article III courts must be jury trials. But no such rule operates as supreme law in the United States.

2) Six-year Senate term for new states. Article I and the Seventeenth Amendment both specify that US senators are elected for six-year terms. ${ }^{69}$ That is in fact the operative rule for most senators. But think about the seventy-eight senators comprising the initial delegations from states admitted to the Union after the First Congress convened. Those thirty-nine statesthat is, the thirty-seven that were not signatories to the Declaration of Independence plus North Carolina and Rhode Island, both of which ratified the Constitution only after the First Congress was sitting-became eligible to elect senators at a whole range of points on the calendar and in odd-numbered as well as even-numbered years. Their initial senators were all elected for lengths of time that would integrate them into the electoral cycle on which one-third of the Senate begins a new six-year term every two years. From Samuel Johnston of North Carolina, who was elected for a three-year term, to Hiram Fong of Hawaii, whose initial term was four and a half years, those senators have been elected for a whole variety of term lengths corresponding to nothing that appears in the text of the Constitution.70

This approach to senatorial terms for new states is reasonable. It is in some ways simpler, perhaps more elegant, and maybe in modern times less expensive for senators to be elected in three big groups than to have Senate seats up for reelection at dozens of different dates, corresponding to the many points in the six-year cycle at which each new state sent its first senators. But the reigning approach is not prescribed by the text. Indeed, it contradicts the text, which states that each senator is elected for a six-year term. ${ }^{71}$ And although the existing system is reasonable, it is not the only way that the situation could be handled. It is perfectly conceivable to imagine senatorial elections occurring on a rolling basis rather than in big batches every two

69 US Const Art I, § 3, cl 1; US Const Amend XVII.

70 I thank Louis Seidman for pointing out this example to me. See Louis Michael Seidman, Acontextual Judicial Review, 32 Cardozo L Rev 1143, 1153-54 \& n 47 (2011).

71 US Const Amend VXII. One could read US Const Art I, $\$ 3, \mathrm{cl} 2$ to mean that the two senators comprising each state's initial delegation should serve terms of different lengths, but the only options for length of term given in the text are two years, four years, and six years. No text authorizes a three-year term or a four-and-a-half-year term. 
years. The Senate already considers itself a "continuing body" rather than one whose business stops and starts as each class is elected..$^{72} \mathrm{~A}$ rolling electoral calendar might bring reality more in line with that conception.

The point here is not that we would be better off if senators were elected at times scattered through the calendar than we are under the present system. It might be better and it might be worse. The point is merely that the existing system declines to implement a clearly stated textual rule and that we should not rationalize the departure on the ground that strict compliance with the text would be crazy or impossible. It wouldn't. We simply have a practice, reasonable on its own terms and sanctioned by tradition stretching back to the beginning, of overriding the term-length rule that is stated in the text. ${ }^{73}$

This example of accepted practice contradicting constitutional text is noteworthy because the violated text is of a kind that the literature generally assumes to be reliably and strictly observed. Even leading nontextualists generally write as if some constitutional texts are reliably treated as supreme and unambiguous law, and the most common illustrations of such texts are numerical rules stating either age qualifications for holding office or the length of time for which officeholders are elected. ${ }^{74}$ This is not quite so. Even in the supposed heartland of textual rules, the text does not always state the operative constitutional rule.

3) Presidential presentment of proposed amendments. The second Presentment Clause of Article I, § 7, states that

Every Order, Resolution, or Vote to which the Concurrence of the Senate and House of Representatives may be necessary

72 See generally Aaron-Andrew P. Bruhl, Burying the "Continuing Body" Theory of the Senate, 95 Iowa L Rev 1401 (2010) (describing and criticizing this conception).

73 To be sure, and in contrast to the example about jury trial under Article III, this textual rule has not been overridden in more than fifty years. But it has been consistently overridden whenever the occasion has presented itself, and it would be overridden again in the future if a new state were to be admitted.

74 See, for example, David A. Strauss, On the Origin of Rules (with Apologies to Darwin): A Comment on Antonin Scalia's The Rule of Law as a Law of Rules, 75 U Chi L Rev 997, 1006 (2008):

There are provisions of the Constitution that do prescribe rules or, in any event, that do not leave much room for discretion. There are provisions that use numbers, for example-for the minimum ages of federal officials, for those officials' terms in office, for the number of senators per state, and for how often a census is to be conducted-and at least the numerical aspects of those rules, read naturally, do not permit the exercise of much discretion. 
(except on a question of Adjournment) shall be presented to the President of the United States; and before the Same shall take Effect, shall be approved by him, or being disapproved by him, shall be repassed by two thirds of the Senate and House of Representatives. ${ }^{75}$

Like the jury trial clause, the Presentment Clause speaks in totalizing and mandatory terms. Every order, resolution, or vote of Congress shall require presidential approval (or a congressional override of the president's veto) in order to become effective.

In practice, however, some prominent congressional orders, resolutions, and votes go into effect without being either signed by the president or repassed by Congress. Notably, Congress proposes constitutional amendments by the joint resolution of both Houses, ${ }^{76}$ and proposed amendments do not go through the presentment procedure. Amendments go into effect upon ratification by the states, with no stop at the president's desk. ${ }^{77}$ Again, the rule stated in the text does not seem to operate as supreme law. 78

As noted before, my claim-that certain practices whose propriety is taken for granted in American law affirmatively contradict rules stated in the text of the Constitution-may not

75 US Const Art I, \& 7, cl 3.

76 The text provides for amendments to be proposed either by joint supermajority resolution in Congress or by a convention that Congress shall call on the application of two-thirds of the state legislatures. See US Const Art V. Only the supermajority resolution has ever been implemented to adopt an actual amendment, so the discussion above is limited to that version of the process.

77 To be precise, twenty-six of twenty-seven amendments have skipped presidential presentment. The sole exception is the Thirteenth Amendment, which President Lincoln did sign before it was sent to the states for ratification.

78 Early litigation under the Eleventh Amendment brought this issue to the Supreme Court, which conspicuously failed to provide a textual explanation for the practice. In Hollingsworth $v$ Virginia, 3 US 378 (1798), one of the claims the Court confronted was precisely that the Eleventh Amendment was invalid because it had not complied with the presentment requirement. Justice Samuel Chase provided the Court's sole response to this contention as follows: "There can, surely, be no necessity to answer that argument. The negative of the President applies only to the ordinary cases of legislation: He has nothing to do with the proposition, or adoption, of amendments to the Constitution." Id at 381. Justice Chase's dictum states the operative supreme law perfectly, and it makes not the slightest gesture toward explaining how the text could be read to accord with that supreme law. More recently, the Supreme Court of Wyoming has interpreted the language of the Wyoming Constitution's presentment requirement, whose wording is in relevant part identical to that of Article $V$, to invalidate a proposed amendment that was not presented to the governor. See Geringer v Bebout, 10 P3d 514, 523 (Wyo 2000). The Supreme Court of Wyoming charitably described the US Supreme Court's reasoning in Hollingsworth as "not contained in that Court's decision." Id. 
persuade all readers. In part because enterprising interpreters can find ways to read the Constitution to mean things that people had not previously understood it to mean, it seems likely that the Constitution could be read to be consistent with prevailing practice on the points I have raised. To be clear, I am not endorsing the position that the text might mean anything. To use Don Herzog's example, I doubt that the Constitution could be read as the story of a small boy growing up in Kansas during the Great Depression.79 I mean instead to make an observation about our capacity to read the Constitution to mean the sort of things that we believe it would make sense for it to mean-to accord, that is, with our constitutional expectations. Thus, the reason why a skilled and dogged textualist should be able to generate the interpretations he needs to persuade himself (and others) that the text of the Constitution does not contain the rules I adduce above is only partly a matter of the indeterminacy of textual meaning. It is also a function of the fact that properly socialized Americans believe that defendants should be able to waive jury trials, that one-third of the whole Senate should be elected every two years, and that the First Amendment is a valid part of the Constitution.

It is not hard to imagine what such readings might look like. Indeed, it is fun to engage in the exercise of trying to generate them. ${ }^{80}$ The important point, though, is that no such readings

79 Don Herzog, As Many as Six Impossible Things before Breakfast, 75 Cal L Rev 609,629 (1987).

80 Here are some examples:

(1) One might deny that Article III makes jury trial mandatory in criminal cases by mobilizing the word "right" in the language of the Sixth Amendment, which guarantees criminal defendants "the right to a speedy and public trial, by an impartial jury of the State and district wherein the crime shall have been committed." This use of the term "right," the textualist might say, indicates that the accused has the option of a trial. To be sure, the term "right" does not always describe an option, see generally Richard A. Primus, The American Language of Rights (Cambridge 1999), but the term does bear that meaning often enough to make such a reading of the Sixth Amendment plausible as a prima facie matter. One could then privilege that interpretation of the Sixth Amend. ment over the apparent plain meaning of Article III in either of two ways. First, one could say that the Sixth Amendment overrides Article III wherever the two conflict because the Sixth Amendment was adopted two years later. See Schick v United States, 195 US 65, 68-69 (1904) (endorsing this reading in dicta). Alternatively, one could say that the two clauses should be read to reflect the same basic idea, that any conflict between them should be resolved by giving each clause a reasonable rather than a literal meaning, and that the apparently inflexible language of Article III is reasonably read just as a way of emphasizing the importance of the jury trial right. As I have described elsewhere, we can think of these two reconciliations as reflecting hard-textualist and soft-textualist approaches, respectively, where the hard textualist insists on a close reading 
of the words and the soft textualist argues that one should not read literally what is meant to be read reasonably. As it happens, the Supreme Court long ago chose a softtextualist reconciliation on this point. See Patton v United States, 281 US 276, 298-99 (1930) (holding that the mandatory language of Article III could not actually have been intended to make jury trial mandatory). In my own view, neither of these readings makes sufficient sense of the text. Given the normal practice of disfavoring implied repeal of constitutional text, it would make more sense to read the Sixth Amendment as guaranteeing that the accused's (mandatory) jury trial would be speedy and public, and that the jury would be impartial and local, rather than as sub silentio jettisoning the requirement of jury trial stated in Article III. But the fact that a reading is textually less sensible than some other reading does not guarantee that that reading will not emerge as the official account of a constitutional practice, especially when that practice is of generally accepted validity.

(2) One might reconcile the practice of varied term lengths for a state's inaugural senators by describing the election of such a senator as the filling of a vacancy rather than as an election of its own. Article I, $\S 3$ is reasonably read to imply that senators elected to fill vacancies should not serve full six-year terms but instead should serve only as long as is necessary to effectuate the policy "that one third [of all senators] may be chosen every second Year." US Const Art I, § 3, cl 2. To be sure, it may seem odd to think of election to a new office as the filling of a vacancy. Both as a matter of ordinary language and in the context of $\S 3$, "vacancy" seems to refer to the condition that obtains when an existing office lacks an occupant, and the inaugural senators from new states have generally not assumed offices that ever existed in that empty state. Instead, these senators have generally taken office immediately upon the states' admission to the Union, such that the office is occupied as soon as it comes into existence. (The selection of officeholders has taken place before the effective date of admission precisely so as to avoid leaving the seats "vacant.") And for what it may be worth, early interpreters seem to have thought that a "vacancy" in the context of Article II could arise only when an incumbent departed the position. See Letter from Alexander Hamilton to James McHenry (May 3, 1799), in Harold C. Syrett, ed, 23 The Papers of Alexander Hamilton 94, 94 (Columbia 1976) ("Vacancy ... presupposes that the Office has been once filled."); Edmund Randolph, Opinion on Recess Appointments (July 7, 1792), in John Catanzariti, ed, 24 The Papers of Thomas Jefferson 165, 165-66 (Princeton 1990). I doubt that this problem would prevent committed textualists from judging, sincerely, that the vacancy exception is a valid textual ground for the practice: again, our constitutional expectations do a lot to make otherwise-awkward textual interpretations seem perfectly reasonable. I note, however, that if the terms of inaugural senators were intended to comply with the constitutional text by virtue of the vacancy exception, one might expect new states to observe a convention of leaving the seat unoccupied for a day, or even an hour, before filling it. No such convention exists, in part because no one has bothered to invoke the vacancy-filling idea as a means of reconciling this practice with the text. As with the waiver of jury trial, the prevailing practice is simply to do something that seems intuitively sensible and not to mind, or even notice, that the text says something else.

(3) One could argue that the presentment procedures make no sense as applied to proposed constitutional amendments because the necessary vote for congressional approval of such proposals - two-thirds of each house-is the same as that required to overcome a veto. See US Const Art I, § 7. If one assumes that Congress could override any veto of a proposed amendment, one might think that insisting on presentment is pointless. But as experienced lawmakers know, the fact that one can muster the support to pass something once does not always mean that one has enough support to pass the same thing twice, even with the same legislature in place, so this argument does not quite establish what it purports to even on its own terms. Alternatively, one could argue that the requirements of Article I, $\S 7$ do not apply to Article $V$ amendments because 
are now part of the shared consciousness of American constitutional practitioners. Reconciling readings of the text would be called into existence and made conventional only as a way of resolving the dissonance that people would experience if the mismatch between prevailing practice and an untutored reading of the text were brought into the foreground. As long as that mismatch remains out of sight, there is constitutional text that does not function as supreme law. More generally, we should be aware that our inclination to see instances of non-operative constitutional text as few and marginal is predicated on our willingness to forgo reading constitutional clauses in ways that they surely could be read as a matter of textual interpretation. The Sixth Amendment's statement that "[i]n all criminal prosecutions, the accused shall enjoy the right to a speedy and public trial, by an impartial jury"si could easily be read to mean that the right to jury trial attaches in (not to put too fine a point on it) all criminal prosecutions. We don't read it that way; we understand the jury trial guarantee to exclude petty offenses, even when denominated criminal.82 Without the power and widespread acceptance of many reconciling readings like that one, inoperative constitutional text would be more pervasive. ${ }^{83}$

Article $\mathrm{V}$ states its own conditions for the validity of measures enacted thereunder. If those conditions are exclusive, the presentment requirement of Article I would not apply. One problem with this argument, though, is that the language of Article I seems totalizing. It provides that "Every" measure to which both Houses must agree must be presented. Note too that congressional enactments under all other articles of the Constitutionnot just those enacted under Article I-are treated as if the Presentment Clause meant what it says. Congressional reorganizations of the judiciary under Article III must be presented to the president, as must measures exercising the various powers given to Congress in Article IV (that is, the power to prescribe interstate comity under the Full Faith and Credit Clause, the power to admit new states, and the power to make rules governing federal territory and disposing of federal property). Statutes adopted under the enforcement clauses of the Thirteenth, Fourteenth, Fifteenth, Nineteenth, TwentyFourth, and Twenty-Sixth Amendments are treated as subject to the presentment requirements of Article I, as is the exercise of the substantive congressional powers conferred in the Sixteenth, Twentieth, Twenty-Third, and Twenty-Fifth Amendments. (The joker in the deck is congressional confirmations as specified in the Twenty-Fifth Amendment, namely the confirmation of a new vice president and the decision as to whether a disabled president is fit to resume office; to date, there is scant practice under these provisions, and it is easy to imagine presidents skipping signatures in both situations.) Considered in this context, a claim that Article $V$ is exempt resembles special pleading - which, again, does not mean that the argument would not be persuasive to a motivated audience.

81 US Const Amend VI.

82 See Duncan v Louisiana, 391 US 145, 159-61 (1968).

83 Some interpreters identify certain constitutional texts as failing to operate as supreme law precisely because they endorse readings of the text that are not obvious to 


\section{Text and formal entrenchment.}

We come now to the one combination of constitutional elements that does seem to travel in a bundle all the time. If a rule appears in the text of the Constitution, the statement of the rule-not the content of the rule or its practical operation, but the textual statement of the rule-cannot be changed except by Article $\mathrm{V}$ amendment. To be sure, the content of the rule might change. In practice, the content of textual rules sometimes changes without formal amendments, often as a result of developments in judicial doctrine. "[N]o Warrants shall issue, but upon probable cause" 84 is a rule that has been understood to permit at some times what it has prohibited at others, even though the text of the rule has not been changed. ${ }^{85}$ What does not change except by Article $V$ amendment is the words of the Constitution itself. ${ }^{86}$ The fact that the text does not change except by amendment has consequences for constitutional law even if the entrenchment of the text does not guarantee entrenchment of any particular content. The text is an important and easily mobilized resource in constitutional argument, and the set of persuasive

all other readers. Professor Ernest Young, for example, regards the prevailing permissive doctrine toward congressional delegations to administrative agencies as abrogating the Vesting Clause of Article I, which states that "All legislative Powers herein granted shall be vested in a Congress of the United States." See Young, 117 Yale L J at 446-47 (cited in note 11). It is not clear, of course, that a nondelegation rule must be read into those words: that a power is vested in Pablo might say nothing about whether he may authorize Tyrone to exercise the power as his agent. (My edition of Black's Law Dictionary specifies that a "vested estate" includes a right of alienation. See Black's Law Dictionary 809 (abridged 5th ed 1983).) Professor Young reads the Vesting Clause as he reads it, though, and on his reading delegation is prohibited, which means that in his view Article I, \& 1 should be added to the list of constitutional texts that do not operate as supreme law. The point, of course, is simply that the extent to which we recognize nonsupreme constitutional text is a function of how assiduously we conform our sense of the right readings of the text to the practice that actually prevails.

84 US Const Amend IV.

85 Contrast, for example, Mapp v Ohio, 367 US 643, 655-57 (1961) (excluding evidence gathered in warrantless search), with Wolf $v$ Colorado, 338 US 25, 33 (1949) (permitting the admission of such evidence).

86 Or at least it never has so far; one can generate far-flung hypothetical circumstances in which such change might be possible. To date, however, it does describe American constitutional practice well to say that the text itself changes only with formal amendments. One might also add the caveat that whether the Constitution has been formally amended as prescribed in Article $\mathrm{V}$ is itself sometimes a contestable question. See, for example, Bruce Ackerman, 2 We the People: Transformations 197-98 (Belknap 1998) (raising doubts about whether the Fourteenth Amendment was adopted in accordance with Article V's requirements); Laurence $H$. Tribe, The Invisible Constitution xixwx (Oxford 2008) (describing controversy over whether the Twenty-Seventh Amendment was validly adopted). 
arguments that are easily made would shift if the text were to change. That said, the fact that text and formal entrenchment are authentically bundled together is less consequential on this understanding than it would be if entrenching the text were tantamount to entrenching the content of an operative rule of law.

\section{Text without judicial review.}

This separation is well known under the heading of the political question doctrine. To take one of the classic examples, the text contains a rule stating that the United States will guarantee each state a republican form of government. ${ }^{87}$ Courts will not enforce the rule. ${ }^{88}$

\section{Supremacy without text.}

The text of Article I empowers Congress to set the date on which congressional elections are held, ${ }^{89}$ and the text of Article II empowers state legislatures to decide how each state's presidential electors will be appointed. ${ }^{\circ 0}$ As a matter of plain reading, these authorizations permit legislators to pursue their partisan interests far beyond the point where American officeholders feel themselves required to stop acting in a partisan fashion. What restrains their pursuit of partisan interest is the sense that it would violate the rules.

Consider Congress first. If both Houses of Congress had majorities of the same political party, and assuming also a friendly president or veto-proof supermajorities, Congress could set the date of each federal election in a way calculated to maximize the chances that the party in power would prevail. Maybe the incumbents would do better if elections were held in June, when the economy will probably be good, than in November, when things might have gone sour. The national legislatures of other democracies engage in such gamesmanship regularly, ${ }^{91}$ but

87 See US Const Art IV, $\$ 4$.

88 See Luther $v$ Borden, 48 US 1, 42 (1849). As noted earlier, statements about what courts will not do are limited by our inability to foresee all the ways in which the future might be different from the past. See Part I.A.4. Perhaps under some future circumstance a court would in fact enforce the Guarantee Clause. What we can say now is that prevailing doctrine includes a principle against the judicial enforcement of that Clause and that courts to date have conformed, at least officially, to that doctrine.

89 US Const Art I, $\S 4, \mathrm{cl} 1$.

90 US Const Art II, $\$ 1, \mathrm{cl} 2$.

91 See, for example, Fixed-Term Parliaments Bill, 515 Parl Deb, HC (6th ser) 621 (2010); Robert Hazell, Fixed Term Parliaments 5, 10-15 (UCL 2010); Peers End Deadlock 
Congress never does, even at a time in history when the parties seem bent on extracting every possible bit of partisan advantage in other ways.

Similarly, state legislatures might allocate electoral votes by themselves, rather than risking the possibility that the citizenelectorate might vote for the other party's presidential candidate. In Michigan, both houses of the legislature presently have Republican majorities and the governor is a Republican. In the last presidential election, Michigan's electoral votes went to the Democratic candidate, and predictably so. The text of Article II indicates that the legislature was not required to permit that outcome. It could have chosen, months before the election, to award Michigan's electoral votes according to its own partisan preference. But well-socialized Americans know that, no matter what the text says, there are no foreseeable circumstances in which a state legislature would eliminate popular voting for presidential electors. Indeed, it would not happen even if doing so would yield the enormous political prize of changing the outcome of a presidential election..$^{92}$

Actions like these are close to unthinkable because the relevant officeholders understand themselves as bound to respect a certain set of rules, rules that legislatures cannot alter on their own authority. ${ }^{93}$ But neither rule is present in the text. On the

over Fixed Term Parliaments (BBC News Sept 14, 2011), online at http://www.bbc.co.uk/news/uk-politics-14924982 (visited Sept 11, 2013).

82 In recent years, a few legislators have entertained the idea of splitting their states' electoral votes in proportion to the statewide popular vote, rather than awarding the entire electoral slate to the winner of the popular vote. The motivations for this idea are understood to be partisan: the proposal surfaces in states where the partisan preference of the legislature differs from the expected partisan preference of the state's presidential electorate, such that splitting the electoral vote proportionally would probably capture more votes for the legislature's preferred candidate than a winner-take-all system would. See, for example, Reid Wilson, The GOP's Electoral College Scheme, Natl J (Dec 17, 2012), online at http:/www.nationaljournal.com/columns/on-the-trail /the-gop-s-electoral-college-scheme-20121217 (visited Sept 11, 2013). Today, Maine and Nebraska already operate on something other than a winner-take-all basis. Accordingly, it is not the case that the winner-take-all system functions as supreme law. What functions as supreme law is the principle that the electors must be awarded pursuant to the popular vote. There is more than one way to translate a popular-vote result into a slate of electors, but no state considers skipping the popular vote and letting the legislature pick electors directly.

93 It is tempting to explain the behavior in part by reference to a fear of electoral blowback from a disgusted citizenry. Note, however, that in the example of congressional elections, that explanation is inapposite. By hypothesis, the majority party will do better electorally if it manipulates the date than if it doesn't. Moreover, in both cases the idea that the voters would punish officeholders who exercised these powers rests on the idea that the electorate regards the legislature as subject to a higher norm. 
contrary, a plain reading of the text authorizes the very things that the legislators regard as forbidden. ${ }^{94}$

\section{Supremacy without Article V entrenchment.}

In its pure form, the big- $C$ theory maintains that no supreme rule of law can be changed, and no new such rule created, except through the mechanisms described in Article V. Almost everyone recognizes, though, that in practice the content of operative constitutional law can be altered through a different mechanism: persuading a majority of the justices of the Supreme Court. Today, the holdings of controversial cases like Roe $v$ Wade $^{95}$ and Citizens United $v$ Federal Election Commission ${ }^{96}$ operate as supreme law in the United States. Many practitioners seek to change that supreme law. Their efforts are focused on securing changes in judicial decisionmaking, not on Article V amendments. If either group succeeds in changing the supreme law, it will almost surely be through the mechanism of judicial decisionmaking, not through Article V.

Similarly, the earlier discussion of the two-term limit for presidents prior to 1940 provides an example of supreme law that can be changed without Article V. While it lasted, the twoterm limit operated as supreme law for the second of the two reasons articulated above: it was a norm that people did not attempt to transgress even when it was in their interests to do so, because the relevant actors considered themselves to be under the authority of a rule. When the norm collapsed, Article V played no role. ${ }^{97}$

6. Supreme law not enforceable through judicial review.

The example of the two-term limit for presidents prior to 1940 also illustrates that supreme law need not be judicially enforced. It seems likely that at no time in history would any court

94 This is not an example of supreme law that contradicts the text. Congress has chosen the November date for elections, and state legislatures have chosen to let popular voting allocate presidential electors. The point is simply that the operative supreme law today does not stop with the proposition that the legislatures choose. It continues to the proposition that the legislatures are not free to revise some of the choices that have already been made.

95410 US 113 (1973).

96558 US 310 (2010).

97 See Part I.A. 
have blocked an attempt to violate the two-term rule, and indeed no court tried to block Roosevelt when he ran a third time.

For another example with Rooseveltian overtones, consider the rule that the Supreme Court has nine justices. Despite frequent manipulation of the number of justices during the nineteenth century, ${ }^{98}$ the rule that the number is fixed at nine seems now to have acquired the status of supreme law. Formally, the source of that rule is a statute that Congress could change like any other statute. 99 Congress does not regard itself as free to exercise that power.

Consider the enormous gains that a majority party could realize by changing the size of the Court. Suppose that in 2009, Democratic supermajorities in Congress had expanded the Court to eleven members, thus giving President Obama two new appointments and the Court a majority of Democratic appointees. The safety of the Affordable Care Act ${ }^{100}$ would have been assured, to say nothing of the consequences for abortion, campaign finance, and who knows what else. But the idea never arose-it's simply off the table.

That said, if Congress did decide to change the size of the Court, it is hard to imagine the courts declaring the change invalid.101 The judiciary lacks a language or a rubric for explaining why this statute, which Congresses changed for partisan advantage several times before the twentieth century, could not be changed again today. It seems, therefore, that the rule that the Supreme Court's size is fixed at nine operates as supreme law but not as law that courts would enforce. ${ }^{102}$

98 See An Act Supplementary to the Act Entitled "An Act to Amend the Judicial System of the United States" $§ 1,5$ Stat 176, 176-78 (1837) (increasing the number of Justices from seven to nine); An Act to Provide Circuit Courts for the Districts of California and Oregon, and for other Purposes $§ 1,12$ Stat 794, 794-95 (1863) (increasing the number to ten); An Act to Fix the Number of Judges of the Supreme Court of the United States, and to Change Certain Judicial Circuits, 14 Stat 209, 209-10 (1866) (reducing the number to seven); An Act to Amend the Judicial System of the United States § 2, 16 Stat 44, 44-45 (1869) (increasing the number to nine).

99 See 28 USC \& 1 ("The Supreme Court of the United States shall consist of a Chief Justice of the United States and eight associate justices.").

100 Patient Protection and Affordable Care Act ("Affordable Care Act"), Pub L No 111-148, 124 Stat 119 (2010).

101 See Dorf, How the Written Constitution Crowds Out the Extraconstitutional Rule of Recognition at 70-71 (cited in note 64) (reaching the same conclusion).

102 Caution counsels us not to say with absolute certainty that the courts would not intervene. We cannot know the future, and courts sometimes develop previously unforeseen justifications for novel exercises of judicial review. Indeed, the sense that government has transgressed a boundary that nobody ever believed could possibly be crossed 
7. Article V entrenched without text.

Suppose that the president, exercising his commander-in-chief power, ${ }^{103}$ orders military personnel to take Catholic communion on the eve of battle, believing sincerely that doing so will increase the likelihood of military victory. Under present law, that order would violate the First Amendment right to the free exercise of religion. The idea that the Free Exercise Clause can be applied against the president, however, is not one that can be derived by reading the words of the First Amendment. Those words announce a limitation on the powers of Congress, not the powers of the president. That said, the idea that the First Amendment binds the president as well as Congress is a deeply rooted part of the operative supreme law, and it is hard to imagine its being changed by mere statute. 104

Given that the operative supreme law subjects the president to the dictates of the Free Exercise Clause, it is easy to assume that freeing the president from those strictures would require an Article V amendment. If that were so, the rule that the president is bound by the Free Exercise Clause (or the First Amendment more generally) would be an example of a nontextual rule that can only be changed through the process of Article V. But on careful consideration, the rule that the First Amendment applies to the president might not be entrenched by Article $V$ as an operative matter, even though it clearly operates as supreme law.

As discussed earlier, a rule is operatively Article $\mathrm{V}$ entrenched if no other avenue of change is as available as change by the Article $\mathrm{V}$ process. To be sure, no non-Article $\mathrm{V}$ process presently seems like a plausible route toward sheltering the president from the First Amendment. But Article V also seems like a complete nonstarter toward that end. A proposed constitutional amendment authorizing the president to prohibit the free

often inspires just such doctrinal developments. But this is true only sometimes. Sometimes the real enforcement mechanisms, such as they are, lie elsewhere. In cases like this one, "elsewhere" includes the internalized attitudes of officeholders, the fear of electoral retribution, and some inarticulate combination of the two. Note too that the fear of electoral retribution rests on the assumption that the electorate regards the size of the Court as fixed by a law that the legislature is under an obligation not to transgress.

103 US Const Art II, $\S 2$, cl 1 ("The President shall be Commander in Chief of the Army and Navy of the United States.").

104 See Andrew B. Coan, The Irrelevance of Writtenness in Constitutional Interpretation, $158 \mathrm{U}$ Pa L Rev 1025, 1085 (2010) (noting "that the First Amendment bars President Obama from forcibly shutting down Fox News ... is uncontroversially true, given the contemporary state of American constitutional law"). 
exercise of religion would never get out of committee. One does not really report a practical feature of the constitutional system, therefore, by saying that Article $\mathrm{V}$ is what stands in the way of a change to this constitutional rule. What prevents a change to this rule is the near-complete absence of support for such a change. The practical role of Article $\mathrm{V}$ as the force holding the rule in place is reminiscent of the practical role of Lisa Simpson's tiger-repellant rock: no tigers enter the town of Springfield when Lisa holds the rock, but only Homer Simpson thinks that the rock is what secures the outcome. ${ }^{105}$ For Article V to be the force entrenching the rule in a practically meaningful way, it would have to be the case that a movement to change the rule enjoyed some support and that the Article $\mathrm{V}$ process was the mechanism by which that movement was most likely to succeed-either because success through that route seemed plausible or because success through other routes seemed less plausible still.

Perhaps we could imagine, in a dystopian vein or otherwise, a political future in which many people sought to give the president more latitude to enforce the law or command the military without the pesky strictures of individual-rights claims like those that free exercise doctrine might support. 106 Under those circumstances, identifying Article $\mathrm{V}$ as the measure of the rule's entrenchment would make sense if the movement for change had enough support to persuade three-fourths of the state legislatures but not enough support to persuade the Supreme Court to revise the case law. (Change in the case law would make amendment unnecessary and demonstrate that the true measure of entrenchment had been the Court's opposition rather than Article V.) So: Is it plausible to imagine that such a change would secure the broad political support necessary to navigate Article $\mathrm{V}$ before securing the support of five justices?

When considering that question, bear in mind that the president seeking the power to require military personnel to take communion would also be the president who most recently made

105 See The Simpsons: Much Apu about Nothing (Fox Television Broadcast May 5, 1996).

106 Some commentators may think this general scenario is already not so far away, albeit applied to constitutional rights other than religious free exercise. See, for example, Noah Feldman, Obama's Drone Attack on Your Due Process (Bloomberg Feb 8, 2013), online at http://www.bloomberg.com/news/2013-02-08/obama-s-drone-attack-on-your-due -process.html (visited Sept 11, 2013) (describing an administration white paper on the use of drone strikes as an evisceration of the constitutional guarantee of due process). 
Supreme Court appointments. Bear in mind too that this president would have been chosen by an electorate willing to have a president who would seek this power. Those facts might color our sense of how the Court might be disposed toward the question. Consider also that the litigants trying to persuade the Court to change would insistently point to the text of the First Amendment, a plain reading of which would vindicate their position. Nontextual rules are easier for courts to enforce when public consensus regards those rules as obviously correct. ${ }^{107}$ In the absence of consensus, or in the face of broad-based opposition, a nontextual rule might be harder for judges to defend. By the time an Article $\mathrm{V}$ amendment becomes plausible, therefore, it might well not be necessary.

That said, one can also imagine the Court's holding its ground, at least for a while, and during that interval Article V would in fact be the easiest route to changing the constitutional rule. Suppose that the question of the president's power to order troops to take communion came before a Court dominated by justices appointed fifteen years earlier, by a more civillibertarian president. Perhaps those justices would stand firm even as public opinion shifted. Finding themselves unable to persuade the Court, the president's allies could mount a campaign to amend the Constitution. If public opinion favored the president's position broadly enough, the rule might change through Article V before the Court gave way.

Short of intricate examples like these, it is hard to identify nontextual rules that one can confidently say are entrenched, in a practical sense, by the terms of Article V. That difficulty largely reproduces the difficulty with knowing that any rule is Article $\mathrm{V}$ entrenched as an operative matter. Once an idea has enough support among decisionmakers to navigate the Article V process, it may also have enough support to be adopted without the need for Article $\mathrm{V}$ because enough decisionmakers (including judges) come to consider it sensible to understand existing constitutional law as already containing, or at least as already compatible with, that idea. ${ }^{108}$ Amendments are more likely to be necessary

107 See Richard Primus, Public Consensus as Constitutional Authority, 78 Geo Wash L Rev 1207, 1220-21, 1227-28 (2010) (explaining that public consensus can act as an independent source of authority in constitutional interpretation).

108 See Strauss, 114 Harv L Rev at 1462-63 (cited in note 50). It also sometimes happens that the decisionmaking class's collective support for the merits of an idea still does not yield the view that the Constitution can be read to embody that idea. The 
in instances when the Supreme Court is out of step with the bulk of the decisionmaking class. Under those circumstances, Article $\mathrm{V}$ offers an easier route to change than judicial revision. Accordingly, nontextual rules can be Article $\mathrm{V}$ entrenched when the Court is standing up for a nontextual rule that is broadly unpopular outside the Court. That is not the normal case, but it can happen from time to time.

\section{Article $\mathrm{V}$ entrenchment but not supreme law.}

Consider two observations described earlier in this Article. First, there are rules stated in the text of the Constitution that do not operate as supreme law. ${ }^{100}$ Second, the text of the Constitution itself is Article V entrenched: we do not alter that text except when Article V amendments are adopted.110 (The meaning we attribute to that text changes without amendments, but the text itself does not.)

It follows from those two observations that the rules that are stated in the text but do not operate as supreme law are, to the extent that they are rules at all, rules entrenched by the terms of Article V. Thus, the text states that all criminal trials in Article III courts must be jury trials. No such rule is followed in practice. The rule is a rule in some nominal sense, not in an operative one. It is not the supreme law. But the statement of that rule that appears in Article III could be changed only by Article $\mathrm{V}$ amendment.

Once again, the fact that these verbal formulas cannot be changed without amendments means considerably less than it would if those formulas stated operatively supreme rules of law. But the fact that the words remain even as practice fails to conform is not completely meaningless. The words in the text are always available as mobilizable resources in constitutional argument. If in the future there were a movement to eliminate federal bench trials, it would draw support from the language of Article III-language that would still be there to call upon, in spite of long practice in apparent derogation of the language,

Twentieth, Twenty-First, and Twenty-Second Amendments-among others-are probably best understood in that vein.

109 See Part I.B.1 (text but not supreme law).

110 See Part I.B.2 (discussing text and formal amendment). 
because the long practice did not eliminate the text. Only Article $\mathrm{V}$ amendment would do that. ${ }^{111}$

9. Article $\mathrm{V}$ entrenched but not enforceable through judicial review.

A rule falling into this category would be one that legislatures believed themselves unable to change except by Article V amendment-or perhaps, one that legislatures considered inadvisable to change except by Article $\mathrm{V}$ amendment-even though the courts would not get in the way of other attempted methods of change.

Consider again the rule that the Supreme Court has nine members. Formally, the rule is statutory. If Congress were to amend 28 USC $\$ 1$ by increasing the number of justices to eleven, it is hard to imagine the Court striking the new statute down. That said, Congress seems strongly disinclined to change the size of the Court even when doing so would be to the manifest advantage of the party in power. That disinclination stems from legitimacy concerns, derived perhaps partly from the historical meaning of President Franklin Roosevelt's court-packing plan and partly from a more abstract sense that the nine-justice Court should not be manipulated. If some future Congress felt it necessary to change the size of the Court, therefore, the relevant decisionmakers might think it safer to do so by Article $V$ amendment, which seems like an unimpeachable method of change, than to make the change by statute. That judgment might be understood as prudential. One might say that Congress legally could increase the size of the Court statutorily if it wanted to, such that it is misleading to say that such a change must go through Article V. But on the understanding that a rule is in practice Article $\mathrm{V}$ entrenched only when there is no easier route to change than Article $\mathrm{V}$ amendment, the relevant question here is not whether there is some other method of change available. It is whether some other method of change is easier than Article V. And for the purpose of deciding whether Article $\mathrm{V}$ offers the easiest route to change, it makes little difference how the considerations making other routes more difficult than Article $\mathrm{V}$ are characterized. What matters is that if the change can be made at all, it will be made under Article V.

111 Or so we reasonably assume. Nothing in American practice to date has suggested another mechanism. 
This example is speculative. Perhaps a Congress determined to have its way with the Court would act by statute regardless of prudential considerations. Perhaps it would be backed by a sufficiently supportive public so as to eliminate the need for prudence-something that seems plausible if an Article $\mathrm{V}$ supermajority were willing to approve the change. Or perhaps Congress would proceed by statute, reluctantly, precisely because it lacked confidence that three-fourths of the states would climb on board. More optimistically, perhaps the scenario for enlarging the Court would be one of partisan comity. If both major parties agreed that the Court needed eleven justices, Congress might pass a law adding two seats after the president had agreed to nominate someone chosen by the majority leader of the Senate-a member of the rival party-to one of the new seats, thus preventing the expansion from seeming like a partisan manipulation. For all of these reasons, it is possible to imagine circumstances under which the rule setting the size of the Court could be changed by statute, and in those circumstances the rule would not be Article V entrenched. But it is also possible to imagine circumstances in which Article $V$ was the best or even the only plausible route to change, even though a statutory change would not be invalidated by an exercise of judicial review.

\section{Judicial review without text.}

States are immune from many federal statutory actions for damages brought by their own citizens, even though the text of the Eleventh Amendment speaks only of actions brought by citizens of other states. ${ }^{112}$ Congress may not commandeer state executive officials. ${ }^{118}$ States may not purposely impede interstate commerce. ${ }^{114}$ The federal executive is bound by the First Amendment. ${ }^{115}$ All of these rules are enforced by courts exercising the power of judicial review. None of them is present in the text of the Constitution.116 Earlier, I illustrated a continuum of textuality along which constitutional rules can be arranged, and

112 See Seminole Tribe of Florida v Florida, 517 US 44, 54 (1996).

113 See Printz, 521 US at 935.

114 See Hunt $v$ Washington State Apple Advertising Commission, 432 US 333, 34854 (1977).

115 See Fox Television Stations, 132 S Ct at 2317-19.

116 See Strauss, The Living Constitution at 32-49 (cited in note 12) (describing the common-law system of judicial review where cases are decided based on precedent, and the Constitution plays "at most, a ceremonial role"). 
I noted that people might disagree about where along that continuum any particular rule falls. ${ }^{117}$ But as these examples show, many well-established judicially enforced rules are not taken from the text even on a reasonably generous understanding of what it means for a rule to be textual.

\section{Judicial review but not supreme law.}

Many rules often thought of as constitutional defaults fall in this category. Consider dormant commerce doctrine. Courts will invalidate state laws that purposely burden or discriminate against interstate commerce, but Congress can override the judiciary and permit a state to burden interstate commerce in a way that the courts would otherwise forbid.118 The judicial restriction is defeasible by ordinary federal legislation and therefore not supreme law. Similarly, consider the exclusionary rule. Courts will exclude evidence gathered in violation of the Fourth Amendment, but not if a legislature creates an adequate alternative remedy. ${ }^{119}$

\section{Judicial review but changeable without Article $\mathrm{V}$ amendment.}

Default rules like those just canvassed are on point again here. The exclusionary rule and the rules of dormant commerce doctrine can be changed by ordinary legislation. But there is also another important set of rules falling into this category. The normal and easiest way to change many judicially enforced constitutional rules is to persuade a majority of Supreme Court justices to revise or overrule existing doctrine, either by getting one or more sitting justices to reverse course or by waiting for the appointment of different justices. The rule that states may not unduly burden a woman's choice to have an abortion and the rule that Congress may not prevent the use of corporate funds to pay for election advertisements are both rules that the courts now enforce through exercises of judicial review. Various actors now seek to change or eliminate one or both of these rules. They generally recognize that the path to change does not run through Article V.

117 See Part I.A.

118 See, for example, Hillside Dairy Inc v Lyons, 539 US 59, 66 (2003); Maine v Taylor, 477 US 131, 138 (1986).

119 Mapp, 367 US at 651-63. 
The vision of constitutionality as a status with a single basis (the text) and three payoffs (supremacy, entrenchment, and judicial review) has some considerable virtues. It captures a great deal of what is supposed to be valuable about American constitutionalism. It aligns with what most well-informed Americans would probably say if asked what it means for something to be a constitutional rule. It helps both to enable and to constrain the practice of judicial review. But it fails to describe the way the constitutional system operates in practice, and the failure does not consist in getting some marginal details wrong. In practice, many rules that exhibit one or more of these four properties do not exhibit one or more of the others. Perhaps most crucially, many rules that do not find their basis in the text are commonly called constitutional rules and exhibit other characteristics of constitutional rules, including enforcement through the power of judicial review.

As noted above, few sophisticated practitioners contend that this bundled vision accurately captures exactly how constitutional law operates in practice. For some, the bundled big-C vision or something like it is a critique of existing practice: to the extent that this vision does not map the practice, the argument runs, the practice is deficient. In my own view, existing practice makes more sense both practically and normatively than would a system in which all textual rules and only textual rules were supreme, entrenched, and judicially enforceable. But a full exploration of this normative controversy would take us far afield. For present purposes, it is enough to note that it is a mistake to think of constitutionality in practice as a bundled status, with text as the basis and the other three characteristics as reliable payoffs.

Just as a person who is willing to indulge sufficiently motivated readings of text can deny that any valid instances of judicial review proceed without textual warrant, a person willing to indulge such readings can assert that every rule stated in the Constitution's text-properly understood-operates as supreme law in the American system. People committed to holding together all of the sticks in big-C theory's constitutional bundle must accordingly exhibit that indulgence. But as the pragmatist logicians taught, anything may be held true come what may, so long as one is prepared to do enough violence to everything 
else. ${ }^{120}$ If innovative and fanciful readings are the price to be paid for maintaining the big-C bundle as a description of American practice, it should be clear that textuality will no longer be doing some of the central work that is claimed to be its virtue: that is, rendering the content of constitutional law stable and determinate. And if one thinks that a successful descriptive account of American constitutionality should be less tendentious, the big-C vision will not do the trick. It pays to consider alternatives.

\section{The SMall-C BundLe(S)}

An important collection of constitutional-theory literature is based on the idea that the written Constitution is not the only source of constitutional authority. ${ }^{121}$ In current convention, this literature is often called "small-c" theory, because it focuses attention on the small-c American "constitution"-that is, on a set of rules and norms and institutions that guide the process of government-rather than on the big-C "Constitution," which is the 1787 document as amended.122 Small-c theories vary a fair amount on a variety of points, but they share an insistence on nontextual constitutionality.

The basic small-c move can be understood as a partial unbundling of the idea of constitutionality. By distinguishing between textuality and constitutional status, small-c theories take one of the sticks in the big-C bundle-text-and contend that it can be separated from the others. Crucially, however, small-c theory tends not to unbundle the idea of constitutionality too much further. Like the big-C approach, small-c commonly presents constitutionality as a bundle of attributes, some of which are the bases of constitutionality and some of which are its payoffs.

The idea of a set of payoffs that follow from constitutional status is crucial to much small-c thinking. After all, one major goal of much small-c theory is to justify the practice of nontextual judicial review. ${ }^{123}$ Commonly, the strategy for doing so is to

120 See, for example, Willard Van Orman Quine, Two Dogmas of Empiricism, in Willard Van Orman Quine, From a Logical Point of View: Logico-Philosophical Essays 20 (Harvard 1953).

121 See notes 9 and 11. See also Strauss, The Living Constitution at 34-35 (cited in note 12).

122 See, for example, Eskridge and Ferejohn, A Republic of Statutes at 1 (cited in note 9); Levinson, Constitutional Faith at 29 (cited in note 6); Young, 117 Yale L J at 414 (cited in note 11).

123 The work of Professors David Strauss and Thomas Grey provides examples. See generally Strauss, The Living Constitution (cited in note 12). See also Grey, 27 Stan L 
show that something other than text is a legitimate basis of constitutional status. To draw attention to something that usually is taken for granted, that strategy works if judicial review is a payoff of constitutional status. If it is, and if something other than text can underlie constitutional status, nontextual rules will be entitled to judicial review. But as illustrated earlier with respect to a simpler model, the idea that constitutionality is a status with a known set of payoffs is misleading. ${ }^{124}$ It remains misleading when applied to the more complex world of small-c constitutionalism.

\section{A. Six Sticks}

As noted above, small-c theory comes in many different varieties, and different small-c theories focus on different aspects of constitutionality. Nonetheless, it is possible to capture the broad range of rules that small-c theorists deem constitutional by reference to six characteristics. Four of those characteristics are familiar from the big-C framework: text, supremacy, entrenchment, and judicial enforceability. As I will discuss, these concepts are sometimes understood in different and less formal ways within the rubric of small-c theory. To those four characteristics, small-c theory adds two other concepts, each of which is a potential justification for treating a rule as constitutional. Drawing on Professor Charles Black, we can call one of those concepts "structure."125 Modifying a suggestion by Professor Philip Bobbitt, we can call the other one "ethos."126 Structure and ethos supplement or sometimes replace text as qualifying grounds for constitutional status.

In what follows, I briefly describe what each of these six concepts means within the rubric of small-c theory. I begin with three apparent bases of constitutional status: text, structure, and ethos. I then consider judicial review, which is often the most important payoff of constitutional status but which is sometimes also a basis of that status. Finally, I consider

Rev at 706-10 (cited in note 7). There are also important exceptions: sometimes small-c theory aims to explain why certain rules that have been thought constitutional should in fact not be enforced through judicial review. See, for example, Ackerman, 1 We the People: Foundations at 131-33 (cited in note 50); Llewellyn, 34 Colum L Rev at 40 (cited in note 16).

124 See Part I.B.

125 See Black, Structure and Relationship at 9-11, 29-32 (cited in note 32).

126 See Bobbitt, Constitutional Fate at 90-106 (cited in note 12). 
supremacy and entrenchment. These are generally understood as payoffs, albeit payoffs that small-c theory often understands in relatively fluid ways.

\section{Text.}

Small-c theory denies that all constitutional rules are textual, but it does not usually deny that text plays an important role in identifying constitutional rules. On the contrary, most small-c theorists think of the text of the written Constitution as a sufficient basis for a rule's constitutionality.127 They simply insist that there are also other bases that can be sufficient in the absence of text. 128

\section{Structure.}

Many constitutional propositions concern the structure of government. Indeed, on one understanding of the small-c term "constitution," the structure and modes of operation of a government are exactly what that government's constitution is. ${ }^{129}$ This idea has many echoes in American small-c theory. Thus, the constitution in a small-c sense might be "the order and structure of the body politic,"130 or "the institutional arrangements" that are "the fundamental political institutions of a society." 131 In the same vein, constitutional rules might be those that tell us how lawmaking is done ${ }^{132}$ or, more broadly and metaphorically, those that serve as the rules of the game.133

For the pure big- $\mathrm{C}$ theorist, the structural propositions with constitutional status are the ones that can be found in the text

127 See, for example, Levinson, Constitutional Faith at 29 (cited in note 6) (describing the core of the difference between big- $\mathrm{C}$ and small-c perspectives as being the exclusivity, vel non, of the text); Black, Structure and Relationship at 30-31 (cited in note 32).

128 See, for example Levinson, Constitutional Faith at 29 (cited in note 6); Strauss, $63 \mathrm{U}$ Chi L Rev at 904 (cited in note 15).

129 See, for example, Young, 117 Yale $\mathrm{L} J$ at 415-16 (cited in note 11); Tiedeman, The Unwritten Constitution at 16 (cited in note 11); Bagehot, The English Constitution at 4-6 (cited in note 10); Aristotle, Constitution of Athens at 83, 113-16 (cited in note 10); Llewellyn, 34 Colum L Rev at 31 (cited in note 16).

130 Tiedeman, The Unwritten Constitution at 16 (cited in note 11).

131 Strauss, 114 Harv L Rev at $1459-60$ (cited in note 50).

132 See William N. Eskridge Jr, America's Statutory "constitution", 41 UC Davis L Rev 1, 12 (2007).

133 See Levinson, 124 Harv L Rev at 700 (cited in note 9). 
of the written Constitution. ${ }^{134}$ Within small-c theory, however, structure is often a source of constitutional authority going considerably beyond the text. ${ }^{135}$ The main thrust of Professor Charles Black's canonical lectures on constitutional structure, for example, was that judges confronting constitutional questions whose substance deals with the structure of government and the relationship among its institutions should reason directly from those considerations of structure and relationship, rather than considering themselves obligated to reason only from the words of the Constitution's text.136

Examples of constitutional rules arising more from structure than from text include those regarding dormant commerce, state sovereign immunity, legislative delegation, commandeering, and many others, arguably including the norm of judicial review. To be sure, people can argue about the extent to which some or all of these norms are grounded in the text, and as always it is possible to find a tremendous amount in the text if one is willing to entertain sufficiently tendentious textual interpretations. But constitutional rules like the ones listed above are more straightforwardly explained in structural terms, such that accepting the legitimacy of structural, nontextual constitutional authority exempts one from having to endorse awkward textual readings. Whether for that reason or others, the idea that structure can be a valid nontextual source of constitutional rules enjoys widespread if quiet acceptance among leading American practitioners. Supreme Court justices and even Supreme Court majorities sometimes forthrightly acknowledge that structure rather than text underlies a given constitutional rule. ${ }^{137}$

134 See, for example, John F. Manning, Federalism and the Generality Problem in Constitutional Interpretation, 122 Harv L Rev 2003, 2039-40 (2009) (arguing against the practice of recognizing constitutional structure apart from constitutional text).

135 See, for example, Gillian E. Metzger, The Constitutional Legitimacy of Freestanding Federalism, 122 Harv L Rev F 98, 103-05 (2009).

136 Black, Structure and Relationship at 12-13, 22-23 (cited in note 32). To be sure, Black often seemed to have an expansive conception of structure, as well as a heightened sense of how clearly that structure-or a particular view of that structure-would resolve a given question.

137 See, for example, Central Virginia Community College v Katz, 546 US 356, 375 (2006) ("'W] have understood the Eleventh Amendment to stand not so much for what it says, but for the presupposition of our constitutional structure which it confirms.") (brackets in original), quoting Blatchford $v$ Native Village of Noatak, 501 US 775, 779 (1991); Printz v United States, 521 US 898, 905 (1997) (Scalia) ("Because there is no constitutional text speaking to this precise question, the answer to the CLEOs' challenge must be sought in historical understanding and practice, in the structure of the Constitution, and in the jurisprudence of this Court."). To be sure, justices also sometimes deny 
To ground a constitutional rule in considerations of structure is to justify it on a substantive basis rather than a formal one. A pure structural argument does not claim that some rule qualifies for constitutional status because it was enacted by an authoritative process or because it appears in an authoritative list of constitutional rules. Instead, the claim that a rule qualifies on structural grounds for constitutional status is a judgment that some set of facts about the institutions of government justifies treating that rule in a certain way-for example, as supreme law, or as entrenched against revision, or as enforceable through the power of judicial review. ${ }^{138}$ Thus, the structural argument for dormant commerce doctrine relies on a judgment about the appropriate roles of state governments, and the structural argument for judicial review relies on a judgment about the appropriate role of courts vis-à-vis other institutions in light of the competences and predictable pathologies of each. ${ }^{139}$

On the big-C conception, the desirability of removing such substantive judgments from constitutional law is precisely why constitutional status should follow only from the formal criterion of adoption as part of the Constitution's text. After all, the substantive judgments that underlie structural claims are things about which people disagree. If those judgments are permitted to determine what counts as a constitutional rule, the argument runs, the judiciary will exercise judicial review on the basis of subjective and contestable judgments. That argument is surely true, so a sophisticated small-c theorist should not contest the charge that recognizing structure as a source of constitutionality guarantees conflict about the content of constitutional law. Instead, the small-c theorist might point out that such conflicts

the validity of putative structural rules on the grounds that the text does not support them. See, for example, Department of Revenue of Kentucky $v$ Davis, 553 US 328, 361 (2008) (Thomas concurring) (rejecting dormant commerce doctrine as having "no basis in the Constitution").

138 An argument in favor of recognizing some structural principle as a constitutional rule might have a formal basis if the argument were essentially originalist. That is, one might argue that the principle in question is an authoritative constitutional rule because the Founders intended, expected, or understood it to be so, thus implicitly enacting it when they ratified the Constitution. In such an argument, the fact that the rule in question is structural is incidental to its status as a constitutional rule. What qualifies the rule as constitutional is the authority of an original understanding. The argument about the Eleventh Amendment put forth in Katz and Blatchford is officially of this variety. See note 137.

139 See, for example, Richard H. Fallon Jr, The Core of an Uneasy Case for Judicial Review, 121 Harv L Rev 1693, 1699-1700 (2008) (offering such an argument). 
reflect differences of judgment that are inevitable in identifying constitutional rules. Indeed, such differences of judgment occur even when the constitutional rules in question are thought to be grounded in the text.140

The idea that structure underlies the constitutional status of many constitutional rules is not intended to make constitutional law determinate by eliminating those differences in judgment. Whether or not we recognize structure as one of the bases for constitutionality, American legal discourse will feature a great deal of conflict about which rules are entitled to constitutional status. The value of recognizing structure as one basis of constitutionality lies in clarifying the content of that struggle. When we argue about whether something is a constitutional rule, one of the things that often drives the argument is a difference in judgments about structure.

\section{Ethos.}

Small-c theories often accord constitutional status to rules that reflect, or that are asserted to reflect, the deep normative commitments that define Americans as a political community. This rubric is variously described in terms of fundamental principles, ${ }^{141}$ basic national ideals, ${ }^{142}$ tradition, ${ }^{143}$ and in other ways as well. Adapting a term from Professor Bobbitt, I will use the label "ethos" to name this ground of constitutionality. ${ }^{144}$

140 Professor Charles Black put the point in the following unsubtle way: "I do not think I am suggesting that precision be supplanted by wide-open speculation. The precision of textual explication is nothing but specious in the areas that matter." Black, Structure and Relationship at 29 (cited in note 32). One need not condemn all textual explication as specious in order to recognize the strength of the basic point that practitioners confronting structural issues are quite capable of disagreeing even where there are texts on point.

141 See, for example, Tribe, The Invisible Constitution at 128 (cited in note 86).

142 See, for example, Grey, 27 Stan L Rev at 706 (cited in note 7).

143 See, for example, Strauss, 63 U Chi L Rev at 879, 891-94 (cited in note 15) (describing the idea of "rational traditionalism").

144 See Bobbitt, Constitutional Fate at 93-119 (cited in note 12). My use of the term is indebted to, but broader than, Professor Bobbitt's. Professor Bobbitt uses "ethos" not just to name the generic idea that a conception of the values of the American polity can give rise to constitutional rules but to identify one particular value that he sees as generating such rules: limited government. See, for example, id at 230. For small-c theorists other than Professor Bobbitt, however, principles other than limited government may be as important to the American constitutional ethos as limited government is in Professor Bobbitt's view. In my attempt to capture the conception of small-c constitutionalism broadly, therefore, I use the idea of ethos generically, to capture constitutional rules that follow from any prevailing ideas about who we are as a people and what we therefore 
Many constitutional rules protecting individual rights are matters of ethos, but not every "ethical" constitutional principle is best characterized as a matter of individual rights. Constitutional rules arising from ethos, as I am using the term, are any constitutional rules grounded by a deeply held set of judgments about the values of the American polity. There is a great deal of controversy over the content of those values, and that conflict plays out in constitutional discourse. When we argue about whether a public university may use race-based affirmative action in its admissions policy, or whether a state may execute a criminal who committed his crimes as a child, we are arguing about the content of those values that comprise the American ethos. The winning side of such arguments has its views adopted-in whole or in part, depending on the extent of the victoryinto prevailing constitutional law.

On a strict big-C view, of course, the only values entitled to constitutional status are the ones written into the text of the Constitution. On a small-c view, American constitutional law validly includes many rules whose source lies in the fact of the values themselves, irrespective of whether those values are reflected in the text of the Constitution. Many constitutional norms that reflect deep American values are indeed stated or at least gestured at in the Constitution's text, and not just by coincidence. But the small-c perspective points out that the content of constitutional law often tracks the content of the values more closely than it tracks the content of the text. For example, the First Amendment gives freedom of speech a place in the constitutional text, but the constitutional law of free speech goes far beyond the text of the First Amendment. Constitutional protection of free speech runs against all government actors, even though the First Amendment's guarantee is textually addressed only to Congress. ${ }^{145}$ Similarly, the Fourteenth Amendment gives equality a place in the text, but the constitutional law of equal protection runs against the federal government even though the Fourteenth Amendment is textually addressed only to states. ${ }^{146}$ Accordingly, the text reasonably authorizes the big-C theorist to identify free speech and equal protection as constitutional

would or would not do through our political institutions, rather than only those arising from the specific conception of ethos that Professor Bobbitt proposes.

145 See, for example, Brandenburg v Ohio, 395 US 444, 447-49 (1969) (applying free speech protection against a state government).

146 See, for example, Adarand Constructors, Inc v Pena, 515 US 200, 227 (1995). 
values, but if he wants to justify these mainstream applications of those principles, he must resort to creative textual readings. In contrast, small-c theorists can regard the constitutional values of equality and free speech as rooted at least partly in ethos rather than in text. The fact that the textual mentions of those values have narrower scope than operative constitutional law does not create any important problems from this perspective, because the text is assumed to be only one of multiple sources for the values. Constitutional law properly tracks the union of all of the sources rather than only one.

Constitutional rules arising from ethos tend to be tied to narratives of American history, usually heroic ones. To return to the previous examples, it is no accident that free speech doctrine became applicable to states, and equal protection doctrine to the federal government, during the decades of national struggle against Nazi Germany and the Soviet Union. A sense of the meaning of America took shape in light of that historical chapter, and that sense of the national ethos drove changes in constitutional law. ${ }^{147}$ Similarly, the recent conflict over whether the Second Amendment confers an individual right of gun ownership played out in large part as a struggle about the character of the society from which modern America descends. ${ }^{148}$ That said, a tie to a grand national narrative is not always a feature of constitutional rules grounded in ethos. Lived experience can also do the trick. When the Supreme Court in Dickerson $v$ United States $^{149}$ rejected Congress's attempt to limit the requirement of reading Miranda ${ }^{150}$ warnings, it did so in part because the warnings had become embedded in the national culture. ${ }^{151}$ Americans engaged in a highly visible practice for more than a generation, and that practice came to shape how decisionmakers understood who we are as a people.

The category of ethos has fuzzy boundaries, if it has boundaries at all. That fuzziness is not a defect. It is a reflection of the

\footnotetext{
147 See Primus, The American Language of Rights at 177-233 (cited in note 80).

148 See, for example, Reva B. Siegel, Dead or Alive: Originalism as Popular Constitutionalism in Heller, 122 Harv L Rev 191, 194-95 (2008).

149530 US 428 (2000).

150 Miranda v Arizona, 384 US 436 (1966).

151 See Dickerson v United States (No. 99-5525) - Opinion Announcement at 00:2400:33 (Oyez Project 2013), online at http://www.oyez.org/cases/1990-1999/1999/1999 _99_5525/opinion (visited Sept 11, 2013) (Chief Justice Rehnquist explaining, when announcing Dickerson, that the Miranda warnings "have echoed through police stations and on television screens in the thirty-four years since we decided the case of Miranda versus Arizona").
} 
social fact that the set of ideas people recognize as stating constitutional principles on ethical grounds is not sharply delimited. The idea of ethos, like the idea of structure, is not a criterion for deciding whether a given claim about constitutional law should be recognized as valid. It is a generalization intended to capture a set of norms that many people do in practice deem constitutional.

\section{Judicial review.}

The judicial enforceability of constitutional rules plays a critical but slippery role in much small-c thinking. As on the bigC conception, small-c constitutionalism regards many but not all constitutional rules as enforceable by courts exercising the power of judicial review. Indeed, whether it is appropriate to exercise judicial review on the basis of rules not written in the text of the constitution is often the central contested question between big-C and small-c theorists. In such cases, justifying judicial review that is not based on text is an intended payoff of small-c theory.

In some important strains of small-c theory, however, judicial enforceability is not only a payoff of constitutional status. It is also a source of that status. On Professor David Strauss's model of common-law constitutionalism, for example, the process by which judges develop reasoned understandings over time is itself a source of constitutional authority. ${ }^{152}$ Professor Philip Bobbitt's treatment of doctrinal argument as a modality of constitutional reasoning similarly treats the discourse of judges over time as a source of constitutional status. ${ }^{153}$

Like a big-C theorist, a small-c theorist might point to concededly legitimate exercises of judicial review as evidence that the rule being enforced is a constitutional rule. After all, the argument would run, judicial review can only legitimately be exercised on the basis of constitutional rules. But when a big-C theorist makes that inference, he implicitly (or explicitly) takes the legitimacy of the judicial enforcement in question as resting ultimately on the authority of the constitutional text. For Professor Bobbitt, and perhaps also for Professor Strauss, it may be unnecessary to posit an ultimate source of constitutionality prior to judicial behavior. Rather than taking judicial review as a

152 Strauss, 63 U Chi L Rev at 904-05 (cited in note 15).

153 See Bobbitt, Constitutional Fate at 39-58 (cited in note 12). 
practice in need of external justification, these versions of smallc constitutionalism regard judicial review as an accepted feature of the constitutional system. ${ }^{154}$ This does not mean, of course, that anything judges might choose to do would be a legitimate enforcement of a constitutional rule. But it does mean that judges can take prior judicial discussions of constitutionality as legitimate sources for judicial review today, particularly if those prior discussions have been widely accepted, and that judges today may continue the reasoned elaboration of the rules and principles that prior judges have deemed constitutional. ${ }^{165}$ Seen in this light, judicial review is both a payoff and a source of constitutional status.

\section{Supremacy.}

Like big-C theory, small-c theory commonly regards constitutional rules as supreme over nonconstitutional rules. For a long time, some small-c theorists commenting on instances where prevailing practice contradicts the written Constitution have accordingly concluded that the prevailing practice in question reflects a constitutional rule and the rule written in the Constitution is not a constitutional rule. After all, the rule reflected in prevailing practice is the one that is operatively supreme. ${ }^{156}$

Some small-c theorists have brought important nuances to the supremacy idea. For example, constitutional supremacy might be dimensional rather than dichotomous, with different kinds of constitutional rules enjoying different levels of supremacy. Consider the role that Professors William Eskridge and John Ferejohn imagine for a category of laws called "superstatutes." 157 In their view, these statutes are a core component of the small-c constitution, and they are supreme over other forms

154 See, for example, id at 237-38 (describing judicial review as a practice that is fundamental to the system, rather than one in need of external justification).

156 See Strauss, 63 U Chi L Rev at 887, 898 (cited in note 15).

156 See, for example, Tiedeman, The Unwritten Constitution at 89-90 (cited in note 11); Seidman, 32 Cardozo L Rev at 1154 (cited in note 70). These instances contrast with a different and perhaps more common attitude among people who recognize nontextual bases for constitutional law, which is to regard all of the text as supreme law, albeit without being exhaustive of the supreme law. See Levinson, Constitutional Faith at 29 (cited in note 6).

157 William N. Eskridge Jr and John Ferejohn, Super-Statutes, 50 Duke L J 1215, 1216 (2001). 
of law but inferior to the text of the Constitution itself. ${ }^{158}$ Professor Keith Whittington's idea of the "constitutional construction" also names a kind of nontextual constitutional rule that is superior to nonconstitutional law but inferior to law derived from the Constitution's text. ${ }^{159}$ On these conceptions, it remains the case that supremacy over nonconstitutional law is a characteristic of constitutional rules, and there are then further considerations that sort out relationships of supremacy within the constitutional realm.

\section{Entrenchment.}

Entrenchment plays a central role in most small-c conceptions of constitutionality. Indeed, for some small-c theorists, entrenchment is close to being the essential constitutional trait. ${ }^{100}$ But entrenchment on the small-c approach need not be entrenchment according to the terms of Article V. ${ }^{161}$ Indeed, it has become common for small-c theorists to assert that Article V's vision of entrenchment is marginal to American constitutional law in practice, because formal amendment is rarely the real mechanism of constitutional change. ${ }^{162}$

What, then, do small-c theorists mean when speaking of constitutional entrenchment? The answers are varied and sometimes slippery. Depending on the theory, the description of a rule as entrenched might mean that people generally expect the rule to persist for a long time, ${ }^{163}$ that people take for granted that the rule is settled and do not think pragmatically about its

158 See Eskridge and Ferejohn, A Republic of Statutes at 8, 293 (cited in note 9); Eskridge and Ferejohn, 50 Duke L J at 1217 (cited note 157).

169 Whittington, Constitutional Construction at 2 (cited in note 12).

160 See, for example, Seidman, 32 Cardozo L Rev at 1147-48 (cited in note 70); Llewellyn, 34 Colum $L$ Rev at 22 (cited in note 16).

161 Simultaneously asserting that entrenchment is key to constitutionality and that Article $\mathrm{V}$ is not the exclusive form of constitutional entrenchment has been a feature of small-c theory for a very long time. See, for example, Llewellyn, 34 Colum L Rev at 2122 (cited in note 16) (describing "highly probable permanence" as an "essential criterion" of constitutionality and, on the previous page, describing the idea that Article $\mathrm{V}$ amendment is the chief process of constitutional change as "superstitions").

162 See, for example, Strauss, 114 Harv L Rev at 1459 (cited in note 50); Ackerman, 120 Harv L Rev at 1767 (cited in note 32) (arguing that the normal mode of constitutional change is presidential leadership and that the Reconstruction Amendments were necessary only because of the unusual circumstance that an accidental President-Andrew Johnson-opposed the dominant party's program of reform).

163 See, for example, Munro, The Makers of the Unwritten Constitution at 8-9 (cited in note 48). 
costs and benefits, 164 that even the rule's former opponents now regard it as beyond partisan debate, ${ }^{165}$ or that a popular consensus holds that the rule is a good one. ${ }^{166}$ These formulations are all distinct. For any combination of them, we could identify examples of rules that would be entrenched on one conception but not on others. That said, the formulations are also largely overlapping as applied to actual rules, such that many rules could be described as entrenched for more than one of these reasons.

Entrenchment conceived in any of these ways is a matter of degree rather than a binary condition. Along any of these dimensions, a rule can be more or less entrenched. According to some small-c theorists, the degree of a rule's entrenchment mirrors the degree of its constitutionality. Very entrenched rules are very constitutional, and rules that are only somewhat entrenched are less so. ${ }^{167}$ And a complete picture of entrenchment would have to account for the fact that a given rule might enjoy different degrees of entrenchment for several different kinds of entrenchment. One rule might be very entrenched in the sense that people take its settlement for granted but less entrenched in the sense of being supported on its merits by popular consensus; another rule might exhibit the opposite combination. To take the measure of a rule's entrenchment, therefore, it is necessary to ask not just "How much?" but "How much of each kind?"

If entrenchment is conceived in these terms, then there is no formal process that can be guaranteed to entrench a rule. Whether a rule is entrenched is partly a matter of attitudes and partly a matter of the practical obstacles to doing without the rule. To be sure, one can identify processes that might bring about the attitudes and practical circumstances that would make a rule entrenched. If the rule is endorsed by respected persons and institutions, or if persuasive arguments are made for it, or if the right people come to regard it as in their interests, then enough of the necessary people may develop the requisite attitudes for that rule to become entrenched. Similarly, the world might be structured so as to make repudiation of a rule extremely costly, whether deliberately or otherwise. Entrenchment

164 See, for example, Llewellyn, 34 Colum L Rev at 26-27 (cited in note 16).

165 See Eskridge and Ferejohn, A Republic of Statutes at 114 (cited in note 9); Ackerman, 2 We the People: Transformations at 10-11 (cited in note 86).

166 See Eskridge and Ferejohn, A Republic of Statutes at 13 (cited in note 9).

167 See, for example, Seidman, 32 Cardozo L Rev at 1148 (cited in note 70); Llewellyn, 34 Colum $\mathrm{L}$ Rev at 30 (cited in note 16). 
might in some cases be fostered simply by a rule's longevity, if people come to take the rule for granted or to order their affairs around it, thus becoming invested in its continuance. ${ }^{168}$ But no set of steps can be guaranteed to entrench a rule to any particular degree, because there is no formal process that can be guaranteed either to bring about a particular set of attitudes in the population or to forestall decisionmakers' willingness to incur the practical costs of change.

\section{B. Several Bundles}

No small-c theory holds that every constitutional proposition exhibits all six aspects of constitutionality described above. The essential move of small-c theory, after all, is the denial that one of those aspects-textuality-is necessary for a rule to enjoy constitutional status. Nor do small-c theories characteristically insist that all constitutional rules display all of the other features associated with constitutionality. But small-c theories have assembled bundles of their own from within the universe of constitutional characteristics. Classic small-c writers like Professors Charles Black, Thomas Grey, and Philip Bobbitt conceived of constitutionality as a status that bundles structure or ethos (or both) with judicial review. ${ }^{169}$ On their view, rules with appropriate structural or ethical content are constitutional rules, and as constitutional rules they are entitled to judicial enforcement. More recently, some of the most influential small-c literature has developed a conception of nontextual constitutionality that bundles structure and ethos with supremacy and entrenchment but pointedly not with judicial review. Prominent theorists working in this vein include Professors William Eskridge, John Ferejohn, and Keith Whittington. ${ }^{170}$

Each of those conceptions has offered a solution to a prominent problem. Classic small-c writers strove to make it possible to speak openly about nontextual judicial review as a legitimate aspect of constitutional decisionmaking, rather than leaving it

168 See Levinson, 124 Harv L Rev at 707 (cited in note 9).

169 See Black, Structure and Relationship at 11 (cited in note 32) (structure); Grey, 27 Stan L Rev at 706 (cited in note 7) (ethos); Bobbitt, Constitutional Fate at 93-96 (cited in note 12) (both).

170 See Keith E. Whittington, Constitutional Interpretation: Textual Meaning, Original Intent, and Judicial Review 5-7, 11-13, 79 (Kansas 1999); Eskridge and Ferejohn, $A$ Republic of Statutes at 1-2, 7-8 (cited in note 9). 
in the shadows as a practice that dare not speak its name. ${ }^{171}$ As we all know, that effort was not wholly successful. The legitimacy of nontextual judicial review remains hotly contested, and even many people who are not hard-line textualists are inclined to minimize its role. In part, serious discomfort with nontextual judicial review persists because of anxiety that nontextual judicial review means license for judges to impose their subjective views on the polity, rather than remaining faithful to an objective authority worthy of being called law. ${ }^{172}$ The more recent wave of small-c writing offers to solve that problem. By retaining the idea that constitutional rules can arise from sources other than the text but reserving judicial review for constitutional rules that are textual, these theorists make it possible to think about important facets of structure and ethos and supremacy and entrenchment without stoking controversy over nontextual judicial review.

Unfortunately, each of these efforts exhibits the problems with constitutional bundling. In different ways, each obscures the complexity of constitutional law by imagining constitutionality as a status with known payoffs that follow from known bases. Professors Black, Grey, and Bobbitt wrote as if their bases for constitutional status made rules fit for judicial review, when in fact they do so only sometimes. Professors Eskridge, Ferejohn, and Whittington purport to sort the bases of constitutionality into those that yield judicial review and those that do not, but in practice the different elements of constitutionality often combine in ways that their models cannot accommodate. Albeit with different sticks from those used in the simple big-C bundle, these small-c theorists repeat the mistake of imagining constitutionality as a consistently bundled status.

1. Classic bundles: justifying judicial review.

The tendency to treat constitutionality as a status with a bundled set of criteria and payoffs is a prominent feature of classic small-c writing. In particular, much of that literature presents the nontextual bases of constitutional status as

171 See, for example, Black, Structure and Relationship at 31 (cited in note 32) (suggesting that structural interpretation "be brought more clearly into the conscious field"); Grey, 27 Stan L Rev at 706 (cited in note 7) (lamenting the tendency of judges to hide their nontextual reasoning).

172 See Ely, Democracy and Distrust at 43-72 (cited in note 7) (criticizing nontexual judicial review). 
foundations for the payoff of judicial review.173 The basic argument of Professor Charles Black's Structure and Relationship in Constitutional Law, for example, is that the source of many important constitutional rules is structural rather than textual and that those rules, being constitutional rules, should be considered supreme, entrenched, and valid subjects for enforcement through the exercise of judicial review. ${ }^{174}$ Professor Black took judicial review to be a payoff of constitutional status, so his conclusion that a certain set of nontextual rules can be enforced through judicial review follows if he can establish structure as a source of that status. Professor Thomas Grey's Do We Have an Unwritten Constitution? has a parallel shape, but with ethos rather than structure as the criterion for constitutionality. Professor Grey argued that American law has long regarded a set of "basic national ideals of individual liberty and fair treatment" as protected by unwritten constitutional rules that it is the judiciary's role to enforce. ${ }^{175}$ Professor Philip Bobbitt's Constitutional Fate follows both of these leads, identifying both structure and ethos as sources of constitutional authority. ${ }^{176}$ And as Professor Bobbitt explains, the point of identifying sources of constitutional authority-at least in Constitutional Fate-is to understand the practice of judicial review. ${ }^{177}$

Professors Black, Grey, and Bobbitt wrote during a fifteenyear period that followed the heyday of the Warren Court and that included the decision in Roe $v$ Wade. ${ }^{178}$ The practice of nontextual judicial review came under trenchant attack in those years, ${ }^{179}$ and it should not be surprising that leading small-c

173 To be sure, some leading small-c thinkers have had the opposite project: Professors Karl Llewellyn and Bruce Ackerman have both advanced theories of constitutionality arguing for the disentrenchment of norms that would otherwise be considered formally entrenched and eligible for judicial protection. Professor Llewellyn's The Constitution as an Institution, published in 1934, was an argument for letting the elected branches make far-reaching changes in federal governance without judicial interference, and Professor Ackerman's We the People is in large part a defense of the judges' having gotten out of the way of that reform program. See Llewellyn, 34 Colum L Rev at 21-23 (cited in note 16); Ackerman, 2 We the People: Transformations at 99-119 (cited in note 86).

174 See Black, Structure and Relationship at 11, 15 (cited in note 32).

175 See Grey, 27 Stan L Rev at 706 (cited in note 7).

176 See Bobbitt, Constitutional Fate at 74-122 (cited in note 12).

177 See id at 3, 233.

178 Roe, 410 US at 152-54.

179 See, for example, Raoul Berger, Government by Judiciary: The Transformation of the Fourteenth Amendment 1-8 (Harvard 1977); Robert H. Bork, Neutral Principles and Some First Amendment Problems, 47 Ind L J 1, 1 (1971). See also Ely, Democracy and 
thinkers set about arguing that constitutional law properly understood provided justifications for judicial review in defense of rules beyond those written in the text. That said, the practice of understanding constitutionality as a bundled status within which nontextual criteria justify the payoff of judicial review was a common feature of small-c writing long before the Warren Court. To cite just one example, Professor Christopher Tiedeman's The Unwritten Constitution of the United States appeared in 1890, focused on structure as the source of constitutionality, and argued that one of the most important features of the idea that some rules have constitutional status is its ability to legitimize the exercise of judicial review, including judicial review on behalf of individual rights not written into the document. 180

Assuming that prevailing practice is a decent guide to legitimate behavior, theorists like these were right to insist that many structural and ethical rules are appropriate subjects of judicial review, whether or not those rules can be found in the text. As discussed above, settled constitutional law is shot through with nontextual rules.181 Again, one can minimize or even deny that fact if one is willing to indulge sufficiently creative readings of text, but that strategy sacrifices most of what is supposed to make textualism valuable.

It is misleading, though, to explain nontextual judicial review by saying that structural and ethical propositions are entitled to judicial enforcement because they are constitutional. If that explanation seems sensible, it is because we are accustomed to assuming that constitutional rules, as such, are fit for judicial review. And we are so accustomed. But that may be largely because the vision of big- $\mathrm{C}$ constitutionalism continues to be influential, even for people who consciously reject the notion that all constitutional rules are in the text. The big-C vision holds that the text is the valid basis for judicial review. If all constitutional rules are textual, it follows easily that constitutional rules are per se valid subjects of judicial review. But if the category of "constitutional rules" includes nontextual rules rooted in structure

Distrust at 43-72 (cited in note 7) (recognizing the limits of pure textualism but criticizing the idea that judicial review should enforce nontextual fundamental values).

180 See Tiedeman, The Unwritten Constitution at 42-44, 47-49, 67-82, 163 (cited in note 11). Professor Tiedeman knew nothing of the Warren Court, of course. For him, a leading example of sound judicial review without textual warrant was the Court's decision in Slaughter-House. See id at 102-09.

181 See Part I.A. 
or ethos, a rule's constitutionality will indicate its eligibility for judicial review only if we have separately shown that rules rooted in structure or ethos are valid subjects of judicial review. Without that showing, justifying those payoffs on the ground that structural or ethical content makes a rule "constitutional" might be an analytic error or a rhetorical trick.

To be clear, the missing showing about why a rule's structural or ethical content warrants judicial review need notindeed, should not-be an explanation for why all structural and ethical rules are judicially enforceable. Textual rules are not all judicially enforceable, and there is little reason to think that other kinds of constitutional rules would uniformly be. As a matter of prevailing practice, only some structural propositions, and only some ethical ones, are treated as judicially enforceable. Dormant commerce doctrine is built on structural propositions, but the rule setting the size of the House of Representatives is also a structural rule, and indeed a rule that prominent small-c theorists have identified as constitutional in their sense, ${ }^{182}$ but no court would invalidate a statute doubling the size of the House.

There could of course be sound reasons for having judges enforce some structural rules but not others. The federal judiciary might be well positioned to strike down protectionist state legislation but have no good basis for deciding whether the House of Representatives should have 435 members or 500. Similarly, unelected judges might be better than legislatures at applying ethical principles of individual liberty to concrete situations where majority sentiment or the general welfare seem to point in the other direction, even if legislatures are at least as well positioned as courts to reflect and formulate national values in the long run. Without attempting to go deeply into how these principles might apply, one can say that it makes sense to allocate decisionmaking on the basis of institutional-competence considerations like these. ${ }^{183}$

Whether or not institutional competence is the chosen framework, the small-c constitutionalist needs some criteria for determining which propositions, out of the universe of structural 12).

182 See, for example, Whittington, Constitutional Construction at 12 (cited in note

183 That people will disagree about how to apply such institutional-competence criteria does not differentiate those criteria from any other criteria that could plausibly be used instead. 
and ethical norms, are the ones that can be enforced by judicial review. And it would make little sense to say that the judicially enforceable rules are the constitutional ones. That statement might simply collapse constitutionality into fitness for judicial review, such that characterization of a rule as constitutional would announce rather than explain its judicial enforceability. Or else it would pretend to give a reason while actually begging the question, and it would do so by trading on the notion of constitutionality as a bundle of characteristics that travel together, one of which is judicial review. That notion cannot withstand close scrutiny. The characteristics we associate with constitutionality often travel separately, and reasons are needed to explain why particular rules exhibiting some of those characteristics should be treated as if they also had others.

\section{Split bundles: ducking judicial review.}

The tendency to theorize constitutionality as a bundle of criteria and payoffs has also appeared in the work of small-c scholars with a very different set of attitudes toward judicial review. As is widely understood, the idea of nontextual constitutional rules commonly provokes the anxiety that courts will have no sound way of knowing which rules they are authorized to enforce. ${ }^{184}$ That anxiety often pushes people back to big-C constitutionalism, or at least to something near it.185 Recently, however, a number of leading theorists have found another alternative. They recognize a realm of nontextual constitutional law but reserve judicial review for constitutional rules that are textual. In other words, they take the set of constitutional traits and assemble them into not one bundle but two.

Consider a framework developed by Professor Keith Whittington. In a body of writing put forth over a period of several years, Professor Whittington distinguished constitutional rules rooted in the text, which he called "interpretations," from nontextual constitutional rules, which he called "constructions."186

\footnotetext{
184 See text accompanying note 179.

185 Professor Bobbitt's narrative of the rising influence of Justice Hugo Black as a response to the apparent nontextual judging of the midcentury Court offers an exemplary illustration. In Professor Bobbitt's telling, it was precisely the worry that the midcentury Court lacked firm and objective bases for its exercises of judicial review that make Justice Black's endorsement of simple textualism seem so compelling. See Bobbitt, Constitutional Fate at 29-33 (cited in note 12).

186 See, for example, Whittington, Constitutional Interpretation at 5-7, 11-13, 79 (cited in note 170).
} 
Constitutional constructions, Professor Whittington explained, set important ground rules for legal and political behavior on matters of structure and ethos in areas where the constitutional text is silent or ambiguous. For example, Professor Whittington says that the rule whereby the Supreme Court has nine justices is a constitutional construction, as is the freezing of the number of members of House of Representatives at 435 and the rule that these Representatives shall be elected from single-member districts. ${ }^{187}$ In ways like these, Professor Whittington says, a smallc constitution consequentially shapes American government. But in Professor Whittington's view, the constructions that comprise the small-c constitution are a second-class form of constitutional law. They may not conflict with the text of the big-C Constitution. They validly operate only in areas that the big-C text leaves open. And perhaps most importantly, judges may exercise judicial review only on the basis of big-C constitutional text. ${ }^{188}$

This framework groups the various attributes of constitutionality into two separate bundles. One bundle includes text, supremacy, Article V entrenchment, and judicial review. That is the realm of what Professor Whittington calls "constitutional interpretation." The other bundle, which is "constitutional construction," includes structure, ethos, and a de facto form of entrenchment, by which is meant that constitutional constructions have greater staying power than ordinary laws do. (To be clear, "interpretations" as well as "constructions" regularly concern structure and ethos. But what makes constitutional interpretations interpretations is their textuality.) There is nuance here, and the rubric is deservedly influential. Note, however, that this theory of nontextual constitutionalism has no place for nontextual judicial review, indeed emphatically not. By segregating the judicial-review aspect of constitutionality from the nontextual bases of constitutionality, Professor Whittington creates a sys: tem that acknowledges the value of thinking about nontextual propositions as "constitutional" but maintains big-C ideas about the relationship between text and judicial review.

Small-c constitutionalism has a similar limit in the writings of Professors William Eskridge and John Ferejohn. In their view, many federal statutes enjoy constitutional status in a small-c sense. Examples include the Administrative Procedure 
Act, ${ }^{189}$ the Voting Rights Act,, ${ }^{180}$ and the Clean Air ${ }^{191}$ and Clean Water Acts. ${ }^{192}$ Such statutes structure lawmaking and other governmental processes, and they reflect deeply and widely held normative views, and they are relatively entrenched against change-not formally entrenched, but practically entrenched, because the norms they embody enjoy wide and deep support. 193

The idea of laws that are statutory in form but constitutional in essence is a deeply small-c idea, and Professors Eskridge and Ferejohn present it forthrightly as such. They contend, and reasonably, that a small-c constitutional framework is far better than the big-C framework for understanding the important workings of modern American government. ${ }^{194}$ Professors Eskridge and Ferejohn are careful to say, though, that small-c constitutional statutes cannot override the big-C constitutional text. ${ }^{195}$ And though the norms that constitutional statutes embody might color judicial interpretations of the big-C Constitution, the courts may not exercise the power of judicial review on the basis of a statute - not even a constitutional statute. ${ }^{196}$

Like Professor Whittington, Professors Eskridge and Ferejohn deflate the worry that nontextual constitutionalism invites overly subjective exercises of judicial review by grouping the properties of constitutionality into two different bundles. Textual propositions are formally supreme, formally entrenched, and legitimate bases for judicial review. Nontextual constitutional propositions enjoy whatever level of practical entrenchment arises from the consensus that supports them. We can think of this approach as a hybrid of big-C and small-c theories. Yes, these theorists say, we have a small-c constitution, and that fact is important in the operation of American government. But the

189 Pub L No 79-404, ch 324, 60 Stat 237 (1946), codified as amended in various sections of Title 5. See also Eskridge and Ferejohn, A Republic of Statutes at 10-11 (cited in note 9 ).

190 Pub L No 89-110, 79 Stat 437 (1965), codified as amended at 42 USC $\$ 1971$ et seq. See also Eskridge and Ferejohn, A Republic of Statutes at 88-89 (cited in note 9).

191 Clean Air Act of 1963, Pub L No 88-206, 77 Stat 392, codified at 42 USC $\$ 7401$ et seq. See also Eskridge and Ferejohn, $A$ Republic of Statutes at 256 (cited in note 9).

192 Federal Water Pollution Control Act Amendments of 1972, Pub L No 92-500, 86 Stat 816, codified at 33 USC $\$ 1251$ et seq. See Eskridge and Ferejohn, $A$ Republic of Statutes at 256 (cited in note 9).

193 See Eskridge and Ferejohn, A Republic of Statutes at 13 (cited in note 9).

194 See, for example, Eskridge, 41 UC Davis L Rev at 5-6 (cited in note 132).

195 See, for example, Eskridge and Ferejohn, $A$ Republic of Statutes at 1, 8 (cited in note 9).

196 See id. 
written Constitution still has the status that big-C theory has traditionally claimed.

This hybrid approach is in some ways a clever attempt to sidestep central problems in both big-C and small-c theory, rather than a solution to those problems. Professors Eskridge, Ferejohn, and Whittington acknowledge and develop the small-c idea that American law has a category of rules on structural and ethical subjects that seem to be regarded as more powerful or more fundamental than other, ordinary rules, albeit without appearing in the written Constitution. But these theorists decline to wrestle with a central claim of small-c theory, namely that nontextual constitutional rules can be as authoritative, as entrenched, and as much the subject of judicial review as any rule that does appear in the written Constitution. Professor Whittington expressly insists that judicial review may proceed only on the basis of written constitutional rules; Professors Eskridge and Ferejohn say much the same thing, albeit in softer voices. In short, these theorists are tied to a big-C conception of judicial review. And as described above, that conception is inconsistent with prevailing practice. To be sure, the hybrid approach should mitigate the anxiety that other forms of small-c theory often provoke about subjective exercises of judicial review. But it does so by denying the major flaw in big-C theory that small-c theory comes to correct, namely the claim that textuality and judicial review must always be bundled together.

By carving the attributes of constitutionality into two domains, the hybrid theorists execute a partial unbundling of constitutionality. That is an advance over a fully bundled picture of constitutional law: it permits us to see that constitutional rules come in different kinds. But the proposed division between the two domains is itself a misleading form of bundling. It denies the broader range of mix-and-match combinations that actually manifest themselves in practice.

3. Repositioning judicial review.

Finally, consider the work of Professor David Strauss. In a considerable body of work, Professor Strauss has developed the argument that American practice regards constitutional law largely as a body of judicial doctrine that evolves over time in the way that other bodies of common law do, albeit with some influence around the edges from the text of the written 
Constitution. ${ }^{197}$ Professor Strauss's is a thoroughly small-c view. He sees relatively little constitutional law as flowing from the text, 198 and he understands constitutional change to be a process that usually takes place without the text's being formally amended. ${ }^{199}$ But although he sees more routes to constitutional change than are imagined in Article V, Professor Strauss understands resistance to easy change as one of the central virtues of constitutional law. Indeed, much of the point of constitutional law for Professor Strauss is the entrenchment of desirable legal norms against the pathologies and misjudgments of politics.200 The norms that Professor Strauss sees as healthily entrenched tend to sound in structure or ethos, and-not surprisinglyjudicial review is for Professor Strauss a major mechanism of their entrenchment. Professor Strauss adheres powerfully to the view that the content of constitutional law changes with prevailing societal attitudes, ${ }^{201}$ so the entrenchment he seeks is only relative. Still, Professor Strauss sees resistance to the excesses of short-term political decisionmaking as a key virtue of constitutional law. His writing aims in large part to explain the legitimacy of judicial review as a mechanism of that resistance. And, of course, it seeks to do so without recourse to the major big-C ideas about the status of the text, which Professor Strauss regards as fallacies.

Professor Strauss accordingly presents a picture of judicial decisionmaking on which judicial review is exercised on behalf of a set of relatively knowable principles. Crucially, a large part of the knowability of the principles arises from the judicial process itself. Like common-law judges in other legal fields, Professor Strauss says, judges in constitutional cases reason from principles previously articulated by other judges. ${ }^{202}$ The application of those principles sometimes calls for change in the forms of modification, clarification, or other kinds of tweaking. ${ }^{203}$ Sometimes, judges engage in a larger kind of change, if a previously articulated

197 See, for example, Strauss, The Living Constitution at 3 (cited in note 12); Strauss, 114 Harv L Rev at 1458-59 (cited in note 50); Strauss, 63 U Chi L Rev at 87779 (cited in note 15).

198 See, for example, Strauss, $63 \mathrm{U}$ Chi L Rev at 877 (cited in note 15).

199 See Strauss, 114 Harv L Rev at 1457-58 (cited in note 50).

200 See, for example, Strauss, 63 U Chi L Rev at 929 (cited in note 15).

201 See Strauss, The Living Constitution at 42 (cited in note 12); Strauss, 114 Harv L Rev at 1459 (cited in note 50).

202 Strauss, 63 U Chi L Rev at 879, 886-87 (cited in note 15).

203 See Strauss, The Living Constitution at 79-80 (cited in note 12); Strauss, $63 \mathrm{U}$ Chi $L$ Rev at 888 (cited in note 15). 
idea now appears obviously and grievously wrong, but such cases are exceptional. ${ }^{204}$ Throughout, the underlying sources of the constitutional law that judges apply include longstanding practices, the nature of society's fundamental political institutions, and judicial precedents that have been accepted over time and which reflect and codify those underlying sources. ${ }^{205}$ The long acceptance of an important practice or principle-or, perhaps even more so, of a judicial precedent articulating such a practice or principle-indicates that the practice, principle, or precedent enjoys constitutional status. Some such things, Professor Strauss says, "are every bit as much a part of the Constitution as the most explicit textual provision." 208 In light of that constitutional status, those practices, principles, and precedents are fit to be defended by the exercise of judicial review.

As a descriptive account of American practice, Professor Strauss's common-law vision has enormous strengths. And to the extent that that account is accurate, it should deflate-if not completely allay-concerns about runaway judges who, untethered by text, will second-guess democratic lawmaking on the basis of their subjective whims. If courts exercise judicial review on the basis of longstanding accepted principles, and if change occurs only (or even mostly) incrementally and only (or even mostly) when it is clearly indicated, then constitutional judging is not as freewheeling as might be feared.

For present purposes, however, it is important to pay close attention not just to the account Professor Strauss gives of judicial review but to the relationship his approach posits between judicial review and constitutional status. Common-law constitutionalism as Professor Strauss presents it partially repositions judicial review within the constitutional bundle. Rather than seeing judicial review solely as a payoff of constitutional status, common-law constitutionalism understands judicial review as a basis for that status. Many propositions earn their constitutional status precisely because they have been adopted by judges exercising the power of judicial review and the resulting judgments have been steadily reaffirmed over time. That constitutional status, once established, seems to solidify the legitimacy of judicial review for the relevant propositions. Judicial

204 See Strauss, The Living Constitution at 35-36 (cited in note 12); Strauss, $63 \mathrm{U}$ Chi $L$ Rev at 906 (cited in note 15).

205 See, for example, Strauss, 114 Harv L Rev at 1459 (cited in note 50).

206 Strauss, 63 U Chi L Rev at 898 (cited in note 15). 
review is appropriate in these circumstances, Professor Strauss tells us, because the principles on behalf of which judicial review is exercised are constitutional principles, if we understand constitutionality correctly. 207

That move in the argument is worth a little bit of scrutiny. What, exactly, does calling a certain set of nontextual propositions "constitutional" add to the claim that they are fit subjects for judicial review because they are long-accepted judgments that have been reaffirmed over time, reaffirmed in particular through the practice of judicial review itself? One reason to deploy the characterization "constitutional" when describing such propositions is that reasonable communication sometimes calls for shorthands. But that may not be the only reason, or even the principal reason, why Professor Strauss's theory presents itself as an account of constitutionality, rather than just an argument about a complex set of factors that justify the exercise of judicial review.

Within the discourse of constitutional law, establishing that a rule has constitutional status is generally tantamount to persuading one's audience that that rule is supreme, entrenched, and enforceable through judicial review. This is a matter of habits of thought. To the question "Why can courts enforce that rule in the face of a contrary legislative decision?" the answer "Because that rule is a constitutional rule" is presumed to be sufficient. But on reflection, that answer is only sufficient if there is some reason why all rules called "constitutional" are entitled to supremacy, entrenchment, and judicial review. If one already thinks that the long acceptance of some structural or ethical proposition is sufficient justification for judges to treat that proposition as judicially enforceable, the label "constitutional" is a convenient shorthand. But if one is skeptical of that claim, one should be no less skeptical after the label "constitutional" is applied.

My argument is not that we need a theory of constitutionality that will answer the hard questions about the criteria for supremacy, entrenchment and judicial review. It is that we should not turn to a theory of constitutionality to answer those questions. Most helpfully understood, "constitutionality" is a shorthand for several overlapping but differentiable constellations of properties, and no account of bases and payoffs can be accurate

207 See, for example, id. 
as applied to all of the different configurations. Some propositions that are in the text are structural, and some are ethical, and some are both, and perhaps some are neither, and some but not all are supreme or entrenched, and some but not all are fit subjects for judicial review. Some structural propositions and some ethical propositions are properly regarded as supreme, or as entrenched, and some are not; some are fit subjects for judicial review, and some are not.

A general theory of constitutionality will not tell us which are which. For that task, we need separate theories that deal directly with the different sticks in the bundle. For example, a theory that could guide the exercise of judicial review might offer an account of the substantive virtues and vices of that practice in light of what we know about the behavior of courts, the behavior of other governmental decisionmakers, and the aims and values of American government. Obviously, such a theory would have many contestable elements, and it is fanciful to imagine that practitioners of constitutional law would ever reach full agreement on the relevant questions. But at least such a theory would be trying to answer the right questions. Trying to settle the question by reference to the category of constitutionality would beg those questions-and it might be no less contentious.

\section{CONCLUSION}

"Constitutional" is a term of approbation. We use it to mark rules, principles, and values as having an exalted status. But the attributes of that status vary, such that establishing the constitutionality of a rule does not reliably establish much else. It may imply that the rule is textual, or supreme, or entrenched, or enforceable through judicial review, and often those implications will be borne out. But often they will be misleading. To think clearly about a rule, it is important to focus on the separate sticks in the constitutional bundle more than on the question of constitutionality itself. Answering that question may not tell us what we need to know. And when describing a rule as "constitutional," it would often be helpful to specify the sense in which the term is meant.

One might wonder whether this analysis suggests that we should strive to avoid the term "constitutional" and instead always speak directly about the separate substantive attributes to which that label points. I do not think that conclusion follows. Like many other terms that name a variety of different but 
related things, "constitutional" is a reasonable shorthand much of the time. The task before the analyst who would think clearly about the set of things that "constitutional" names is to avoid mistaking the shorthand for a fully specified concept. Besides, any recommendation that American lawyers purge the word "constitutional" from their vocabularies would be quixotic. The term is deeply embedded within our discourse, and the practitioner who tried to do without it would be committing malpractice. Whatever its ambiguities, the description of a rule as constitutional carries a claim, or at least a strong implication, of exalted status, and in an adversarial profession it is unwise to unilaterally disarm oneself of potent rhetorical tools. And in a different vein, the methodological commitments of my analysis suggest that the idea of a bundled status called "constitutionality" is a social fact to be taken seriously, even if the ostensible content of that idea gives way under scrutiny. After all, my analysis is committed to observing the practice of constitutional law as it actually operates. The propensity to bundle the attributes of constitutionality-even if only by creative interpretation and other forms of legerdemain-is a robust feature of the practice of constitutional law, no less so than the reality that many constitutional rules lack one or more of those attributes when carefully considered. Learning to see unbundled constitutional rules is an advance over seeing them only in a simpler way. But the unbundled perspective is not the end of the matter, because the practice sets value on treating constitutionality as bundled. So the constitutional lawyer must be able to rebundle constitutionality as well as to unbundle it, and he must know when-or in what role-to do which.

Exploring the precise dynamics by which prevailing practice strives to maintain constitutionality as a bundled status seems like a fruitful project for another paper. In closing this one, and perhaps to suggest a bridge to that other inquiry, I offer one final set of observations.

Strictly speaking, none of the attributes associated with constitutionality necessarily entails any of the others. But there are some patterns. Above, I noted that structure and ethos are categories into which many rules regarded as constitutional fall, rather than criteria that qualify rules as constitutional. Which structural and ethical norms should be deemed supreme or entrenched or judicially reviewable is a hard question, one that I do not think can be answered wholesale. It is generally the case, 
though, that if a structural or ethical proposition is regarded as supreme or as entrenched-whether in the Article V sense or less formally, meaning that it is treated as not to be revised in the ordinary course-it is likely to be called a constitutional rule. And once we think of it as a constitutional rule, we may come to associate it with the text of the Constitution, even if competent readers of English lacking awareness of the proposition would not find it in the text.

Consider some illustrative examples. Only after decisionmakers developed the substantive intuition that free speech should run against the states and equal protection against the federal government did the textual devices of incorporation and reverse incorporation come to seem natural. Something similar may be happening today with the anticommandeering rule, as it shifts from a nontextual principle to an interpretation of the Necessary and Proper Clause. ${ }^{208}$ In other words, once constitutionality is established, rules may move along the continuum of textuality described above. ${ }^{209}$ Rules that were once recognized as nontextual may become associated with particular clauses by virtue of official stories, and rules that are associated with clauses by virtue of official stories may so color our intuitions about the text that we come to think of the rules as fairly implied by the text rather than merely associated with it. As an official matter, of course, textuality is the paradigmatic basis of constitutional status. But in circumstances like these, textuality is a payoff rather than a source. 


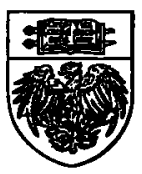

